Prepared in cooperation with the City of Cedar Rapids

\title{
Selected Water-Quality Data from the Cedar River and Cedar Rapids Well Fields, Cedar Rapids, lowa, 2006-10
}

Data Series 657 



\section{Selected Water-Quality Data from the Cedar River and Cedar Rapids Well Fields, Cedar Rapids, lowa, 2006-10}

By Gregory R. Littin

Prepared in cooperation with the City of Cedar Rapids

Data Series 657 


\section{U.S. Department of the Interior \\ KEN SALAZAR, Secretary \\ U.S. Geological Survey \\ Marcia K. McNutt, Director}

\section{U.S. Geological Survey, Reston, Virginia: 2012}

For more information on the USGS - the Federal source for science about the Earth, its natural and living resources, natural hazards, and the environment, visit http://www.usgs.gov or call 1-888-ASK-USGS.

For an overview of USGS information products, including maps, imagery, and publications, visit http://www.usgs.gov/pubprod

To order this and other USGS information products, visit http://store.usgs.gov

Any use of trade, product, or firm names is for descriptive purposes only and does not imply endorsement by the U.S. Government.

Although this report is in the public domain, permission must be secured from the individual copyright owners to reproduce any copyrighted materials contained within this report.

Suggested citation:

Littin, G.R., 2012, Selected water-quality data from the Cedar River and Cedar Rapids well fields, Cedar Rapids, lowa, 2006-10: U.S. Geological Survey Data Series 657, 32 p. 


\section{Contents}

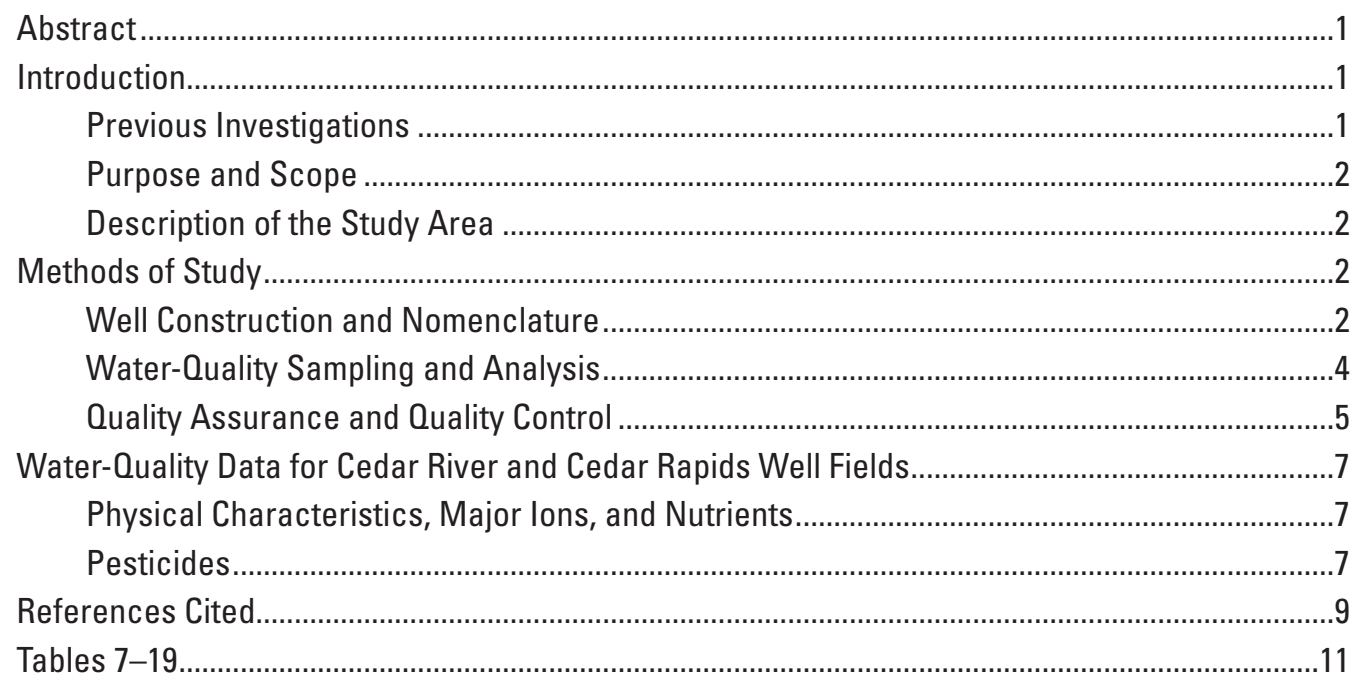

\section{Figures}

1. Map showing groundwater and surface-water quality sampling sites, Cedar Rapids, lowa . 


\section{Tables}

1. Information on groundwater and surface-water quality data-collection sites, Cedar Rapids, lowa, calendar years 2006-10.

2. Nutrients, dissolved organic carbon, and physical characteristics analyzed for in water-quality samples

3. Major ions analyzed for in water-quality samples..............................................................5

4. Selected pesticides analyzed for in water-quality samples. 6

5. Replicate water-quality data for nutrients, major ions, and pesticides in groundwater and surface-water samples, Cedar Rapids, Iowa, calendar years 2006-10

6. Surrogate pesticide data for groundwater and surface-water samples with minimum, maximum, median, and mean percent recovery, Cedar Rapids, lowa, calendar years 2006-10

7. Summary statistics for physical characteristics of groundwater and surfacewater samples, for all sites combined, Cedar Rapids, lowa, calendar years 2006-10

8. Summary statistics for physical characteristics of groundwater and surfacewater samples, by site, Cedar Rapids, lowa, calendar years 2006-10.

9. Summary statistics for major ions in groundwater and surface-water samples, for all sites combined, Cedar Rapids, lowa, calendar years 2006-10..

10. Summary statistics for major ions in groundwater and surface-water samples, Cedar Rapids, lowa, calendar years 2006-10

11. Summary statistics for nutrients in groundwater and surface-water samples, for all sites combined, Cedar Rapids, lowa, calendar years 2006-10.

12. Summary statistics for nutrients in groundwater and surface-water samples, Cedar Rapids, lowa, calendar years 2006-10

13. Summary statistics for major ions and nutrients in groundwater and surfacewater samples, by site, Cedar Rapids, lowa, calendar years 2006-10.

14. Description of pesticides in water-quality samples, Cedar Rapids, lowa, calendar years 2006-10

15. Pesticides that were not detected in water-quality samples, Cedar Rapids, lowa, calendar years 2006-10

16. Selected pesticides detected and frequency of detections in groundwater and surface-water samples, for all sites combined, Cedar Rapids, lowa, calendar years 2006-10

17. Selected pesticides detected and frequency of detections in groundwater and surface-water samples, Cedar Rapids, lowa, calendar years 2006-10.

18. Selected pesticides detected and frequency of detections in groundwater and surface-water samples, by site, Cedar Rapids, Iowa, calendar years 2006-10

19. Virus in groundwater and surface-water samples, by site, Cedar Rapids, Iowa, calendar years $2006-10$ 


\section{Conversion Factors}

\begin{tabular}{|c|c|c|}
\hline Multiply & By & To obtain \\
\hline \multicolumn{3}{|c|}{ Area } \\
\hline square mile $\left(\mathrm{mi}^{2}\right)$ & 2.590 & square kilometer $\left(\mathrm{km}^{2}\right)$ \\
\hline \multicolumn{3}{|c|}{ Length } \\
\hline inch (in.) & 2.54 & centimeter $(\mathrm{cm})$ \\
\hline foot $(\mathrm{ft})$ & 0.3048 & meter (m) \\
\hline mile (mi) & 1.609 & kilometer (km) \\
\hline \multicolumn{3}{|c|}{ Volume } \\
\hline cubic foot $\left(\mathrm{ft}^{3}\right)$ & 0.02832 & cubic meter $\left(\mathrm{m}^{3}\right)$ \\
\hline million gallons (Mgal) & 3,785 & cubic meter $\left(\mathrm{m}^{3}\right)$ \\
\hline \multicolumn{3}{|c|}{ Flow rate } \\
\hline cubic foot per second $\left(\mathrm{ft}^{3} / \mathrm{s}\right)$ & 0.02832 & cubic meter per second $\left(\mathrm{m}^{3} / \mathrm{s}\right)$ \\
\hline million gallons per day (Mgal/d) & 0.04381 & cubic meter per second $\left(\mathrm{m}^{3} / \mathrm{s}\right)$ \\
\hline
\end{tabular}

Temperature in degrees Celsius $\left({ }^{\circ} \mathrm{C}\right)$ may be converted to degrees Fahrenheit $\left({ }^{\circ} \mathrm{F}\right)$ as follows:

$$
{ }^{\circ} \mathrm{F}=\left(1.8 \times^{\circ} \mathrm{C}\right)+32
$$

Vertical coordinate information is referenced to North American Vertical Datum of 1988 (NAVD 88).

Horizontal coordinate information is referenced to North American Datum of 1983 (NAD 83).

Elevation, as used in this report, refers to distance above the vertical datum.

Transmissivity: The standard unit for transmissivity is cubic foot per day per square foot times foot of aquifer thickness $\left[\left(\mathrm{ft}^{3} / \mathrm{d}\right) / \mathrm{ft}^{2}\right] \mathrm{ft}$. In this report, the mathematically reduced form, foot squared per day $\left(\mathrm{ft}^{2} / \mathrm{d}\right)$, is used for convenience.

Specific conductance is given in microsiemens per centimeter at 25 degrees Celsius $(\mu \mathrm{S} / \mathrm{cm}$ at $\left.25^{\circ} \mathrm{C}\right)$.

Concentrations of chemical constituents in water are given either in milligrams per liter (mg/L) or micrograms per liter $(\mu \mathrm{g} / \mathrm{L})$. 


\section{Acknowledgments}

The author thanks the personnel of the Cedar Rapids Water Division for their assistance in data collection and construction of monitoring wells. 


\title{
Selected Water-Quality Data from the Cedar River and Cedar Rapids Well Fields, Cedar Rapids, lowa, 2006-10
}

\author{
By Gregory R. Littin
}

\section{Abstract}

The Cedar River alluvial aquifer is the primary source of municipal water in the Cedar Rapids, Iowa area. Municipal wells are completed in the alluvial aquifer approximately 40 to 80 feet below land surface. The City of Cedar Rapids and the U.S. Geological Survey have been conducting a cooperative study of the groundwater-flow system and water quality of the aquifer since 1992. Cooperative reports between the City of Cedar Rapids and the U.S. Geological Survey have documented hydrologic and water-quality data, geochemistry, and groundwater models. Water-quality samples were collected for studies involving well field monitoring, trends, source-water protection, groundwater geochemistry, surface-water-groundwater interaction, and pesticides in groundwater and surface water. Water-quality analyses were conducted for major ions (boron, bromide, calcium, chloride, fluoride, iron, magnesium, manganese, potassium, silica, sodium, and sulfate), nutrients (ammonia as nitrogen, nitrite as nitrogen, nitrite plus nitrate as nitrogen, and orthophosphate as phosphorus), dissolved organic carbon, and selected pesticides including two degradates of the herbicide atrazine. Physical characteristics (alkalinity, dissolved oxygen, $\mathrm{pH}$, specific conductance and water temperature) were measured in the field and recorded for each water sample collected. This report presents the results of routine water-quality data-collection activities from January 2006 through December 2010. Methods of data collection, quality-assurance, and water-quality analyses are presented. Data include the results of water-quality analyses from quarterly sampling from monitoring wells, municipal wells, and the Cedar River.

\section{Introduction}

The City of Cedar Rapids, in Linn County, Iowa, obtains its municipal water supply from a shallow alluvial aquifer adjacent to the Cedar River. Fifty-three vertical wells and four horizontal collector wells are completed at about 40 to 80 feet (ft) below land surface. Vertical wells gradually are being replaced by higher-yielding horizontal collector wells, but many of the vertical wells are used regularly or are in standby operation. Adequate quantities of generally high-quality water have been obtained from the alluvial aquifer since the resource was developed in 1962. Although, increasing population and industrial development generally have increased the demand for municipal water, Cedar Rapids pumped about 35 million gallons per day (Mgal/d) from the alluvial aquiver in 2010 as compared with nearly $40 \mathrm{Mgal} / \mathrm{d}$ in 2005 , a decrease of about 12 percent. However, peak demands were as much as $49 \mathrm{Mgal} / \mathrm{d}$ at certain times, typically during summer months (T. Baloch, City of Cedar Rapids Water Division, written commun., April 2011). To document the quality of water available from the Cedar River and the alluvial aquifer, the City of Cedar Rapids and the U.S. Geological Survey (USGS) have been conducting a cooperative study of the groundwater-flow system, surface-water system, and water quality in and near the well fields since 1992.

\section{Previous Investigations}

Schulmeyer (1995) analyzed the effect of the Cedar River on the quality of groundwater near the municipal well fields. Schnoebelen and Schulmeyer (1996) documented hydrogeologic data collected and compiled from October 1992 to March 1996. Schulmeyer and Schnoebelen (1998) described the hydrogeology near the municipal well fields, documented a groundwater-flow model constructed to simulate regional groundwater flow under steady-state conditions, identified sources of water to the municipal well fields, and assessed temporal and spatial variations of selected waterquality constituents and properties. Boyd (1998) characterized groundwater flow near the municipal well fields using selected environmental isotopes and tracers. Boyd (1999) evaluated the occurrence and distribution of concentrations of selected pesticides in the alluvial aquifer and Cedar River following springtime application of these pesticides to upstream cropland areas. Boyd and others (1999) further documented hydrogeologic data collected in the Cedar Rapids area from April 1996 to March 1999. Littin and Schnoebelen (2010) documented water-quality data collected in the Cedar Rapids area from calendar years 1999 to 2005 . 


\section{Purpose and Scope}

This report presents the results of water-quality datacollection activities from January 2006 through December 2010 for a study conducted by the USGS, in cooperation with the City of Cedar Rapids, Iowa. Data presented in this report include results of water-quality analyses and physical characteristics of water samples measured during sample collection from the Cedar River, the Cedar Rapids waterworks, and 11 wells in the Cedar Rapids municipal well fields.

\section{Description of the Study Area}

Cedar Rapids is within Linn County in east-central Iowa; municipal water for the City of Cedar Rapids is supplied from three well fields (Seminole, East, and West) along the Cedar River (fig. 1). The City of Cedar Rapids has a population of about 126,300 (U.S. Census Bureau, 2011). Several large industries are major water users resulting in a per capita water usage that is nearly three times the national average for a city of this size (R. Hesemann, Cedar Rapids Water Division, written commun., February 2004). The Cedar River Basin drains an area of about 6,510 square miles $\left(\mathrm{mi}^{2}\right)$ upstream from the stream-gaging station at Cedar Rapids (Cedar River at Cedar Rapids, USGS station number 05464500). Upstream land use is greater than 90 percent agriculture, dominated by corn and soybeans. Livestock raised in the area include cattle and hogs. Average annual precipitation for 2006 through 2010 was about 43 inches (in.) per year in the Cedar Rapids area (Iowa State University, 2011). Extreme daily mean flows recorded at the stream-gaging station during this reporting period were 138,000 cubic feet per second $\left(\mathrm{ft}^{3} / \mathrm{s}\right)$ on June 13,2008 , and $1,270 \mathrm{ft}^{3} / \mathrm{s}$ on December 22, 2008 (U.S. Geological Survey, 2011). Extreme daily mean flows recorded during the period of record (1903-2010) were 138,000 $\mathrm{ft}^{3} / \mathrm{s}$ on June 13, 2008, and $140 \mathrm{ft}^{3} / \mathrm{s}$ on November 18, 1989 (U.S. Geological Survey, 2011).

Hydrogeologic units in and near the well fields consist of an unconsolidated surficial layer of glacial till, loess, and the Cedar River alluvium (alluvial aquifer), underlain by carbonate bedrock of Devonian and Silurian age. The flood plain ranges from about 1,000 to $3,300 \mathrm{ft}$ wide in the study area. The upland topography is characterized by rolling hills of low relief. Typically, glacial till and loess form upland areas that bound the alluvial aquifer. The alluvial aquifer ranges from 5 to $95 \mathrm{ft}$ thick near the well fields and consists of a sequence of coarse sand and gravel at the base, grading upward to fine sand, silt, and clay near the surface. The thickness of the alluvium decreases as distance from the Cedar River increases; the thinnest alluvium is adjacent to the valley walls. The alluvial valley is bounded by steep bluffs that rise almost $200 \mathrm{ft}$ above the river floodplain, and, in places, bedrock is exposed. The bedrock aquifer has a maximum thickness of about $700 \mathrm{ft}$ near the well fields. The bedrock aquifer primarily consists of jointed and fractured limestone and dolomite, with some interbedded chert and shale (Schulmeyer and Schnoebelen, 1998). No municipal wells have been completed in the bedrock aquifer, but it is used locally by private landowners and some industrial users. The unconsolidated surficial layers, carbonate bedrock of Devonian and Silurian age, and deeper hydrogeologic units are described in detail by Hansen (1970), Wahl and Bunker (1986), and Schulmeyer and Schnoebelen (1998).

The alluvial aquifer is recharged by infiltration from the Cedar River, precipitation, and seepage from the underlying bedrock and adjacent hydrogeologic units. In areas affected by municipal pumping, groundwater flow is from the Cedar River toward the well fields; in areas outside those affected by municipal pumping, groundwater flow is toward the Cedar River. The Cedar River is in direct hydraulic connection with the alluvial aquifer (Turco and Buchmiller, 2004). Hansen (1970) calculated an approximate transmissivity of the alluvial aquifer to be about 20,000 feet squared per day $\left(\mathrm{ft}^{2} / \mathrm{d}\right)$. Subsequent investigations by Schulmeyer (1995) indicate that the transmissivity ranges from about 1,500 to $19,000 \mathrm{ft}^{2} / \mathrm{d}$, depending on the physical properties of the alluvium. In May 2006, a contractor to the City of Cedar Rapids performed an aquifer test using Seminole well 10 (an abandoned well located on the edge of the river bank). This aquifer test yielded a transmissivity value of approximately $15,000 \mathrm{ft}^{2} / \mathrm{d}(\mathrm{R}$. Hesemann, Cedar Rapids Water Division, oral commun., March 2007).

\section{Methods of Study}

Samples for water-quality analysis were collected from the Cedar River, monitoring wells within the municipal well fields, municipal wells, and the Cedar Rapids waterworks plant. Data include results of water-quality analyses and physical characteristics measured at the time of sample collection. Well locations used for sampling are shown in figure 1. Statistics (minimum, maximum, mean, and median) were compiled for all water-quality samples. In addition, methods of quality assurance of samples are discussed and data on quality-control samples are presented.

\section{Well Construction and Nomenclature}

Wells sampled during the study included 2- and 4-in. outer-diameter monitoring wells. The monitoring wells were installed using hollow-stem auger drilling techniques and completed with polyvinyl-chloride (PVC) flush-joint casing. Bentonite grout was installed around the casing 6 to $8 \mathrm{ft}$ below land surface, and the wells were capped with a cement pad at the surface. Well depths ranged from 22.5 to $42.5 \mathrm{ft}$. Wellconstruction information for all the monitoring wells is listed in table 1.

The monitoring wells are named according to a convention that includes the year the well was installed (for example, 1993), the agency identifier (USGS), the local project 


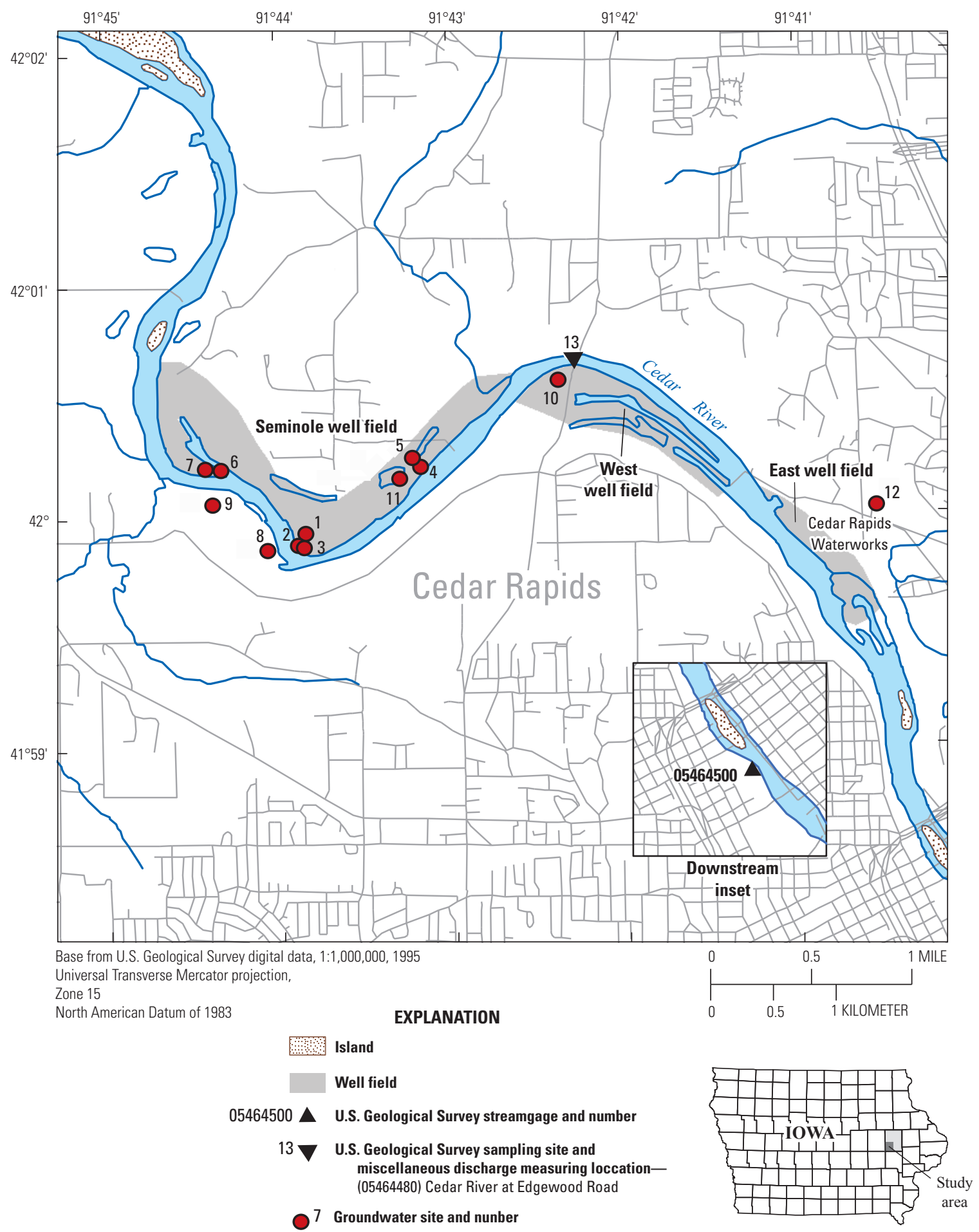

Figure 1. Groundwater and surface-water quality sampling sites, Cedar Rapids, lowa. 
Table 1. Information on groundwater and surface-water quality data-collection sites, Cedar Rapids, lowa, calendar years 2006-10.

[ID, identifier; U, U.S. Geological Survey monitoring well; C, common ions and trace elements; N, nutrients; P, pesticides; A, alluvial; Vi, Virus; V, vertical well; H, municipal multiple-horizontal collector well; --, no data or not applicable; M, municipal multiple-well composite; S, surface water]

\begin{tabular}{|c|c|c|c|c|c|c|c|c|c|c|}
\hline $\begin{array}{l}\text { Map } \\
\text { ID }\end{array}$ & Site name & $\begin{array}{l}\text { Site } \\
\text { type }\end{array}$ & $\begin{array}{l}\text { Type of } \\
\text { water- } \\
\text { quality } \\
\text { samples } \\
\text { collected }^{2}\end{array}$ & $\begin{array}{l}\text { Number } \\
\text { of } \\
\text { samples } \\
\text { collected }\end{array}$ & $\begin{array}{l}\text { Period of } \\
\text { record }\end{array}$ & $\begin{array}{c}\text { Total } \\
\text { depth } \\
\text { (feet } \\
\text { below } \\
\text { land } \\
\text { surface) }\end{array}$ & $\begin{array}{l}\text { Casing } \\
\text { diameter } \\
\text { (inches) }\end{array}$ & $\begin{array}{c}\text { Screened } \\
\text { interval } \\
\text { top/bottom } \\
\text { (feet } \\
\text { below } \\
\text { land } \\
\text { surface) }\end{array}$ & $\begin{array}{c}\text { Land- } \\
\text { surface } \\
\text { elevation } \\
\text { (feet above } \\
\text { mean } \\
\text { sea level)' }\end{array}$ & Aquifer \\
\hline 1 & 1993USGS CRM-3 & U & $\mathrm{C}, \mathrm{N}, \mathrm{P}, \mathrm{Vi}$ & 8 & 2006-2010 & 42.5 & 4 & $40.0 / 42.5$ & 727.00 & A \\
\hline 2 & 1993USGS CRM-4 & U & $\mathrm{C}, \mathrm{N}, \mathrm{P}$ & 2 & 2006-2010 & 42.5 & 4 & $40.0 / 42.5$ & 726.45 & A \\
\hline 3 & 2010USGS CRM-4A & U & $\mathrm{C}, \mathrm{N}, \mathrm{P}, \mathrm{Vi}$ & 4 & 2010 & 42.5 & 2 & $40.0 / 42.5$ & 726.20 & A \\
\hline 4 & 1998USGS CRM-22 & U & $\mathrm{C}, \mathrm{N}, \mathrm{P}, \mathrm{Vi}$ & 23 & 2006-2010 & 22.5 & 4 & $20.0 / 22.5$ & 720.07 & A \\
\hline 5 & 1998USGS CRM-23 & $\mathrm{U}$ & $\mathrm{C}, \mathrm{N}, \mathrm{P}$ & 8 & 2006-2010 & 27.0 & 4 & $22.0 / 27.0$ & 722.07 & A \\
\hline 6 & Seminole 17 & V & $\mathrm{C}, \mathrm{N}, \mathrm{P}, \mathrm{Vi}$ & 17 & 2006-2010 & 58.0 & 30 & $34.0 / 54.0$ & 717.07 & A \\
\hline 7 & Seminole 18 & V & $\mathrm{C}, \mathrm{N}, \mathrm{P}$ & 17 & 2006-2010 & 52.0 & 30 & $32.0 / 52.0$ & 722.90 & A \\
\hline 8 & Ranney 1 & $\mathrm{H}$ & $\mathrm{C}, \mathrm{N}, \mathrm{P}$ & 19 & 2006-2010 & 59.5 & -- & -- & 722.60 & A \\
\hline 9 & Ranney 2 & $\mathrm{H}$ & $\mathrm{C}, \mathrm{N}, \mathrm{P}$ & 19 & 2006-2010 & 49.6 & -- & -- & 722.60 & A \\
\hline 10 & West Ranney 3 & $\mathrm{H}$ & $\mathrm{C}, \mathrm{N}, \mathrm{P}$ & 18 & 2006-2010 & 67.0 & -- & -- & 721.00 & A \\
\hline 11 & Seminole Ranney 4 & $\mathrm{H}$ & $\mathrm{C}, \mathrm{N}, \mathrm{P}, \mathrm{Vi}$ & 21 & 2006-2010 & 64.0 & -- & -- & 720.00 & A \\
\hline 12 & $\begin{array}{l}\text { Cedar Rapids } \\
\text { Waterworks Plant }\end{array}$ & M & $\mathrm{C}, \mathrm{N}, \mathrm{P}, \mathrm{Vi}$ & 22 & 2006-2010 & -- & -- & -- & 745.07 & A \\
\hline 13 & $\begin{array}{l}\text { Cedar River at } \\
\text { Edgewood Road }\end{array}$ & S & $\mathrm{C}, \mathrm{N}, \mathrm{P}, \mathrm{Vi}$ & 28 & 2006-2010 & -- & -- & -- & 720.07 & -- \\
\hline
\end{tabular}

${ }^{1}$ Datum: NAD 88 at CRM4A, all others NAD 29.

identifier, (CRM, for Cedar Rapids Municipal), and a unique incremental number (beginning with number 1). For example, well 1993USGS CRM 3 is the third monitoring well installed by the USGS for CRM. For convenience in this report, the year and agency identifier typically will not be included when referring to a site name.

With the exception of Ranneys 1 and 2, municipal wells used by the City of Cedar Rapids are identified by the well field name (Seminole or West) then the well number (for example Seminole 17, West Ranney 3). Horizontal collector wells that have been added to the well fields during the last 20 years are identified as "Ranney" wells. Ranneys 1 and 2, and West Ranney 3, are labeled Seminole Ranney 1, Seminole Ranney 2, and Edgewood Ranney, respectively, in Littin and Schnoebelen, 2010.

\section{Water-Quality Sampling and Analysis}

Water-quality samples were collected from the Cedar River, 2- and 4-in. diameter monitoring wells, municipal wells, and the Cedar Rapids waterworks plant (municipal-well raw-water composite). Water-quality samples were collected from January 2006 through December 2010, and included quarterly water samples, and, beginning in May 2008, routine virus samples.
Before collecting water samples, each monitoring well was pumped to remove approximately three borehole volumes of water. Water samples were collected using a stainless-steel submersible pump and chemically inert fluoropolymer tubing. Onsite measurements of air temperature, alkalinity, air pressure, dissolved oxygen, $\mathrm{pH}$, specific conductance, and water temperature were performed at the time of sample collection. Dissolved oxygen, $\mathrm{pH}$, specific conductance, and water temperature were measured in a flow-through chamber for groundwater only. Water samples for analysis of nutrients and major ions were filtered through a 0.45 -micrometer $(\mu \mathrm{m})$ pore size polycarbonate capsule filter in the field. Water samples for pesticide analysis were filtered through a $0.7-\mu \mathrm{m}$ pore size borosilicate glass-fiber filter baked at 450 degrees Celsius $\left({ }^{\circ} \mathrm{C}\right)$. All samples were collected according to USGS protocols (U.S. Geological Survey, 2006). Water samples were kept chilled and shipped by overnight air express to the USGS National Water-Quality Laboratory (NWQL) in Denver, Colorado for analysis.

Nutrients, dissolved organic carbon, and physical characteristics analyzed for in the water-quality samples, the Chemical Abstract Service Registry Number (CASRN), the National Water Information System (NWIS) parameter code, laboratory reporting limits (LRL), and reporting units are listed in table 2. This report contains CAS Registry Numbers ${ }^{\circledR}$, which 
Table 2. Nutrients, dissolved organic carbon, and physical characteristics analyzed for in water-quality samples.

[CASRN, Chemical Abstract Service Registry Number; NWIS, National Water Information System; LRLs, laboratory reporting levels; N, nitrogen; mg/L, milligrams per liter; --, not applicable; $\mathrm{P}$, phosphorus; $\mu \mathrm{S} / \mathrm{cm}$, microsiemens per centimeter]

\begin{tabular}{lcccc}
\hline \multicolumn{1}{c}{$\begin{array}{c}\text { Water-quality } \\
\text { constituent }\end{array}$} & $\begin{array}{c}\text { CASRN } \\
\text { number }\end{array}$ & $\begin{array}{c}\text { NWIS } \\
\text { parameter } \\
\text { code }\end{array}$ & LRLs & \multicolumn{1}{c}{$\begin{array}{c}\text { Reporting } \\
\text { units }\end{array}$} \\
\hline Nutrients and dissolved organic carbon & & \\
\hline Nitrogen, ammonia, as N & $7664-41-7$ & 00608 & $0.01-.04$ & $\mathrm{mg} / \mathrm{L}$ \\
Nitrogen, nitrate plus nitrite, as N & -- & 00631 & $.06-.04$ & $\mathrm{mg} / \mathrm{L}$ \\
Nitrogen, nitrite, as N & $14797-65-0$ & 00613 & $.02-.001$ & $\mathrm{mg} / \mathrm{L}$ \\
Phosphorus, ortho, as P & $14265-44-2$ & 00671 & $.02-.006$ & $\mathrm{mg} / \mathrm{L}$ \\
Dissolved organic carbon & -- & 00681 & .40 & $\mathrm{mg} / \mathrm{L}$ \\
\hline & Physical characteristics & & \\
\hline Alkalinity & -- & 39086 & -- & $\mathrm{mg} / \mathrm{L}$ \\
Dissolved oxygen & -- & 31501 & -- & $\mathrm{mg} / \mathrm{L}$ \\
pH & -- & 00400 & -- & standard units \\
Specific conductance & -- & 00095 & -- & $\mu \mathrm{S} / \mathrm{cm}$ \\
Temperature, water & -- & 00010 & -- & degrees Celsius \\
\hline
\end{tabular}

${ }^{1}$ This report contains CAS Registry Numbers ${ }^{\circledR}$, which is a Registered Trademark of the American Chemical Society. CAS recommends the verification of the CASRNs through CAS Client Services ${ }^{\mathrm{SM}}$.

is a Registered Trademark of the American Chemical Society. CAS recommends the verification of the CASRNs through CAS Client Services. The term "nitrate" as used in this report refers to the nitrite species, as this form of the nitrogen species typically is a small concentration (less than $0.1 \mathrm{mg} / \mathrm{L}$ ). The major ions and selected pesticides with two pesticide degradate compounds, followed by the CASRN number, NWIS parameter code, and LRLs are listed in tables 3 and 4, respectively. The LRL is used to specify the lowest quantifiable value for constituents listed in tables 2, 3, and 4. The LRLs for many of the constituents varied during the period of record covered by this report. The LRL is defined more rigorously by statistics than the older minimum reporting level (MRL) that it replaces at the NWQL (Oblinger-Childress and others, 1999).

\section{Quality Assurance and Quality Control}

To properly interpret water-quality data and to verify that these data are reliable and accurate, quality-assurance (QA) procedures and quality-control (QC) samples are needed. In general, quality assurance includes using correct procedures and protocols, proper documentation (log books and field sheets), and approved analytical methods. The QC samples typically are used in the estimation of the magnitude of bias and variability of the environmental samples. Bias is systematic error that can "skew" results in either a positive or negative direction. The most common source of positive bias in water-quality studies is contamination of samples from airborne gases and particulates, or sampling equipment inadequately cleaned between uses and locations. Variability is the degree of random error of independent measurements of
Table 3. Major ions analyzed for in water-quality samples.

[CASRN, Chemical Abstract Service Registry Number; NWIS, National Water Information System; LRLs, laboratory reporting levels; $\mu \mathrm{g} / \mathrm{L}$, micrograms per liter; mg/L, milligrams per liter; --, not applicable]

\begin{tabular}{lcccc}
\hline $\begin{array}{c}\text { Water-quality } \\
\text { constituent }\end{array}$ & $\begin{array}{c}\text { CASRN1 } \\
\text { number }\end{array}$ & $\begin{array}{c}\text { NWIS } \\
\text { param- } \\
\text { eter code }\end{array}$ & LRLs & $\begin{array}{c}\text { Reporting } \\
\text { units }\end{array}$ \\
\hline Boron & $7440-42-8$ & 01020 & 1.8 & $\mu \mathrm{g} / \mathrm{L}$ \\
Bromide & $24959-67-9$ & 71870 & .02 & $\mathrm{mg} / \mathrm{L}$ \\
Calcium & $7440-70-2$ & 00915 & .02 & $\mathrm{mg} / \mathrm{L}$ \\
Calcium & $3983-19-5$ & 00453 & .02 & $\mathrm{mg} / \mathrm{L}$ \\
$\quad$ bicarbonate & & & & \\
Calcium & $471-34-1$ & 00442 & .02 & $\mathrm{mg} / \mathrm{L}$ \\
$\quad$ carbonate & & & & \\
Chloride & $16887-00-6$ & 00940 & .12 & $\mathrm{mg} / \mathrm{L}$ \\
Fluoride & $16984-48-8$ & 00950 & .12 & $\mathrm{mg} / \mathrm{L}$ \\
Iron & $7439-89-6$ & 01046 & $8.0-3.0$ & $\mu \mathrm{g} / \mathrm{L}$ \\
Magnesium & $7439-95-4$ & 00925 & .014 & $\mathrm{mg} / \mathrm{L}$ \\
Manganese & $7439-96-5$ & 01056 & $.4-.2$ & $\mu \mathrm{g} / \mathrm{L}$ \\
Potassium & $7440-09-7$ & 00935 & .02 & $\mathrm{mg} / \mathrm{L}$ \\
Silica & $7631-86-9$ & 00955 & .018 & $\mathrm{mg} / \mathrm{L}$ \\
Sodium & $7440-23-5$ & 00930 & .12 & $\mathrm{mg} / \mathrm{L}$ \\
Sulfate & $14808-79-8$ & 00945 & .18 & $\mathrm{mg} / \mathrm{L}$ \\
Total dissolved & & 70300 & 10 & $\mathrm{mg} / \mathrm{L}$ \\
$\quad$ & & & & \\
\hline \multicolumn{1}{l}{ solids } & & & & \\
\hline
\end{tabular}

${ }^{1}$ This report contains CAS Registry Numbers ${ }^{\circledR}$, which is a Registered Trademark of the American Chemical Society. CAS recommends the verification of the CASRNs through CAS Client Services ${ }^{\text {SM }}$. 
Table 4. Selected pesticides analyzed for in water-quality samples.

[CASRN, Chemical Abstract Service Registry Number; NWIS, National Water Information System; LRLs, laboratory reporting levels; $\mu \mathrm{g} / \mathrm{L}$, micrograms per liter]

\begin{tabular}{lccrc}
\hline $\begin{array}{l}\text { Water-quality } \\
\text { constituent }\end{array}$ & $\begin{array}{c}\text { CASRN } \\
\text { number }\end{array}$ & $\begin{array}{c}\text { NWIS } \\
\text { parameter } \\
\text { code }\end{array}$ & LRLs & $\begin{array}{c}\text { Reporting } \\
\text { units }\end{array}$ \\
\hline Acetochlor & $34256-82-1$ & 49260 & 0.05 & $\mu \mathrm{g} / \mathrm{L}$ \\
Alachlor & $15972-60-8$ & 46342 & .05 & $\mu \mathrm{g} / \mathrm{L}$ \\
Ametryn & $834-12-8$ & 38401 & .05 & $\mu \mathrm{g} / \mathrm{L}$ \\
Atrazine & $1912-24-9$ & 39632 & .05 & $\mu \mathrm{g} / \mathrm{L}$ \\
Bromacil & $314-40-9$ & 04029 & .05 & $\mu \mathrm{g} / \mathrm{L}$ \\
Butachlor & $23184-66-9$ & 04026 & .05 & $\mu \mathrm{g} / \mathrm{L}$ \\
Butylate & $2008-41-5$ & 04028 & .05 & $\mu \mathrm{g} / \mathrm{L}$ \\
Carboxin & $5234-68-4$ & 04027 & .05 & $\mu \mathrm{g} / \mathrm{L}$ \\
Cyanazine & $21725-46-2$ & 04041 & .20 & $\mu \mathrm{g} / \mathrm{L}$ \\
Cycloate & $1134-23-2$ & 04031 & .05 & $\mu \mathrm{g} / \mathrm{L}$ \\
Diphenamid & $957-51-7$ & 04033 & .05 & $\mu \mathrm{g} / \mathrm{L}$ \\
Hexazinone & $51235-04-2$ & 04025 & .05 & $\mu \mathrm{g} / \mathrm{L}$ \\
Metolachlor & $51218-45-2$ & 39415 & .05 & $\mu \mathrm{g} / \mathrm{L}$ \\
Metribuzin & $21087-64-9$ & 82630 & .05 & $\mu \mathrm{g} / \mathrm{L}$ \\
Prometon & $1610-18-0$ & 04037 & .05 & $\mu \mathrm{g} / \mathrm{L}$ \\
Prometryn & $7287-19-6$ & 04036 & .05 & $\mu \mathrm{g} / \mathrm{L}$ \\
Propachlor & $1918-16-7$ & 04024 & .05 & $\mu \mathrm{g} / \mathrm{L}$ \\
Propazine & $139-40-2$ & 38535 & .05 & $\mu \mathrm{g} / \mathrm{L}$ \\
Simazine & $122-34-9$ & 04035 & .05 & $\mu \mathrm{g} / \mathrm{L}$ \\
Simetryn & $1014-70-6$ & 04030 & .05 & $\mu \mathrm{g} / \mathrm{L}$ \\
Terbacil & $5902-51-2$ & 04032 & .05 & $\mu \mathrm{g} / \mathrm{L}$ \\
Trifluralin & $1582-09-8$ & 04023 & .05 & $\mu \mathrm{g} / \mathrm{L}$ \\
Vernolate & $1929-77-7$ & 04034 & .05 & $\mu \mathrm{g} / \mathrm{L}$ \\
CIAT ${ }^{2}$ & $6190-65-4$ & 04040 & .05 & $\mu \mathrm{g} / \mathrm{L}$ \\
CEAT ${ }^{2}$ & $1007-28-9$ & 04038 & .05 & $\mu \mathrm{g} / \mathrm{L}$ \\
\hline & & & \\
\hline & & & \\
& & &
\end{tabular}

${ }^{1}$ This report contains CAS Registry Numbers ${ }^{\circledR}$, which is a Registered Trademark of the American Chemical Society. CAS recommends the verification of the CASRNs through CAS Client Services ${ }^{\mathrm{SM}}$.

${ }^{2}$ Atrazine degradates: 2-Chloro-4-amino-6-isopropyl-amino-striazine (CIAT) and 2-Chloro-4-ethylamino-6-amino-s-triazine (CEAT).

the sample quantity. Variability may be the result of errors in laboratory analytical procedures or in collection of samples in the field. The QA/QC procedures are required to ensure that the data collected meet standards of reliability and accuracy.

The QA/QC procedures for the study followed USGS protocols (US Geological Survey, 2006) and other USGS guidelines (Mueller and others, 1997). Approximately 10 percent of the total samples collected for the study were analyzed for quality control including equipment blanks, field blanks, and replicates. Generally, blanks are used to estimate sample bias whereas replicates are used to estimate sample variability.
A blank is a water sample that is intended to be free of the analytes of interest. Blank samples of deionized water guaranteed by the manufacturer to be free of organic compounds and another type of deionized water guaranteed by the manufacturer to be free of inorganic compounds were passed through all sampling equipment at the beginning of the field season. Equipment blank samples are collected in a "clean" environment, such as the laboratory, to examine the cleanliness of the equipment before sampling. A field blank is a specific type of blank sample collected in the field and used to demonstrate that (1) equipment has been adequately cleaned to remove contamination introduced by samples obtained at the previous site; (2) sample collection and processing have not resulted in contamination; and (3) sample handling, transport, and laboratory analysis have not introduced contamination (Mueller and others, 1997). Field blank samples of the deionized inorganic and organic free water were collected by passing the water through all pumps, filter plates, and filters to verify the cleanliness of sampling equipment and technique. Field blank sample concentrations of inorganic and organic constituents typically were below the LRL. Otherwise stated, the blanks were "clean" and did not indicate any contamination from the equipment or sample processing methods. Results signify no cross-contamination of samples from sampling equipment between sample collection.

Replicates are two or more samples collected or processed so that the samples are considered to be essentially identical in composition. Each replicate sample is an aliquot of the native water sample that is processed and prepared in the same way as the environmental sample. For the purposes of this report, the terms "environmental sample" and "replicate sample" are used to identify the particular samples in a replicate pair.

One objective of collecting replicate samples was to estimate the precision of constituent concentrations determined by sample processing and analysis. Analytical results of organic constituents generally are more variable than those of inorganic constituents. Replicate samples were compared by using relative percent differences (RPD). RPD between replicate samples was calculated using the following:

$$
R P D=|S 1-S 2| /(S 1+S 2 / 2) \times 100
$$

where $S 1 \quad$ is equal to the concentration in the environmental sample, in micrograms per liter $(\mu \mathrm{g} / \mathrm{L})$ or milligrams per liter $(\mathrm{mg} / \mathrm{L})$ and

$S 2 \quad$ is equal to the concentration in the replicate sample, in the same units as S1.

A large relative percent difference can indicate greater variability between samples. Variability for all constituents in the replicate samples generally was within 10 percent of the environmental samples. The median RPD for nutrients, organic carbon, and major ions ranged from 0 to 11.5 percent, 
in terms of absolute value, and the median RPD for pesticides ranged from 0.1 to 15.4 percent (table 5). It should be noted that when comparing small or low concentrations between some replicate samples, the RPD can appear relatively large, because slight differences (common at the lowest detection levels) can result in higher RPDs. This typcially is the case for individual RPDs that had the largest percentage (10 percent or greater).

Surrogates were added to all environmental and qualitycontrol samples for pesticide analysis before sample preparation in the laboratory. A surrogate has physical and chemical properties similar to those of the analytes of interest but is not normally present in environmental samples. Surrogates provide quality control by monitoring matrix effects and gross processing errors (Wershaw and others, 1987), and help control for bias, either positive or negative. Surrogate recoveries of organic chemicals are expressed in percent and typically range from 80 to 120 percent. Surrogate recoveries that consistently are less than 70 percent may indicate that many targeted compounds may be present in greater concentrations than reported. Surrogate recovery rates median percent recoveries (ranging from 74.5 to 92.6 percent), and mean percent recoveries (ranging from 74.5 to 96.3 percent) are listed in table 6 .

\section{Water-Quality Data for Cedar River and Cedar Rapids Well Fields}

The results of the water-quality samples collected from January 2006 through December 2010 are summarized in tables 7 to 19 at the back of this report. Data compiled are primarily from samples collected from the Cedar River, and monitoring wells with quarterly monitoring. Other waterquality data were obtained from surface-water-groundwater interaction studies and the characterization of water quality in shallow groundwater in the Seminole Well Field.

Water-quality data were used to assess quality of water in the alluvial aquifer and the Cedar River. The Cedar River is the major influence on water quality in the alluvial aquifer because of induced infiltration from the river as a result of the pumping of wells (Schulmeyer and Schnoebelen, 1998; Boyd, 1999; Turco and Buchmiller, 2004). Agricultural chemicals (nutrients and pesticides) are of concern because of the predominance of agricultural land use ( 90 percent and greater) in the Cedar River Basin. A 12-mile (mi) reach of the Cedar River upstream from Cedar Rapids, Iowa, is identified on the Total Maximum Daily Load (TMDL) list for nitrate impairment (Iowa Department of Natural Resources, 1994; U.S. Environmental Protection Agency, 2007). Water-quality data were evaluated for nutrients and pesticides, then selected major ions and physical characteristics.

\section{Physical Characteristics, Major lons, and Nutrients}

Nutrient data were compiled for ammonia, nitrate plus nitrite, nitrite, and orthophosphate. Dissolved organic carbon data are summarized with nutrient data. Four samples were analyzed for ammonia plus organic nitrogen (filtered and unfiltered) and phosphorus (filtered and unfiltered). Nutrient summary statistics for groundwater and surface-water from all sites are shown in table 11. Nutrient summary statistics for groundwater samples from the alluvial aquifer and surfacewater samples from the river are listed in table 12. Summary statistics for major ions, nutrients, and organic carbon in water samples from individual sites are listed in table 13.

\section{Pesticides}

Pesticides are used to control unwanted vegetation, insects, and other pests in agricultural and urban areas. Typically, large amounts (thousands of pounds per year) of common herbicides are applied during the growing season in the Cedar River Basin to corn and soybean crops (Schnoebelen and others, 2003). Triazine (atrazine and cyanazine) and chloroacetanilide (acetochlor and metolachlor) generally are the most extensively used herbicides in eastern Iowa. Insecticides are detected less often in water, most likely because they are used in smaller amounts than herbicides, have short persistence, and are selectively applied during periods of reduced runoff (Schnoebelen and others, 2003). Pesticide degradates are formed when a parent pesticide compound breaks down or degrades. Pesticide degradates often have been detected at higher concentrations than their parent compounds (Kolpin and others, 2000, Kolpin and others, 2004, and Schnoebelen and others, 2003). The pesticide degradates of atrazine: 2-Chloro-4-ethylamino-6-amino-s-triazine (CEAT) and 2-Chloro-4-amino-6-isopropyl-amino-striazine (CIAT) were the only two degradates regularly analyzed. These two degradates (CEAT and CIAT) are included in all tables listing the pesticides. Pesticide sampled for during the study period and their uses are listed in table 14. Pesticides that were tested for but not detected are listed in table 15 .

Pesticides detected in water samples from all sites are listed in table 16. Pesticide detections in groundwater samples from the alluvial aquifer and surface-water samples from the river are shown in table 17. Pesticide detections by individual site are listed in table 18. Seven sites (CRM-3, CRM-4A, CRM-22, Seminole 17, Seminole Ranney 4, Water Treatment Plant, and Cedar River at Edgewood Road) were sampled for enteric viruses and are listed in table 19. 
Table 5. Replicate water-quality data for nutrients, major ions, and pesticides in groundwater and surface-water samples, Cedar Rapids, lowa, calendar years 2006-10.

$[\mathrm{mg} / \mathrm{L}$, milligrams per liter; $\mathrm{N}$, nitrogen; $\mathrm{P}$, phosphorus; $\mu \mathrm{g} / \mathrm{L}$, microgram per liter $]$

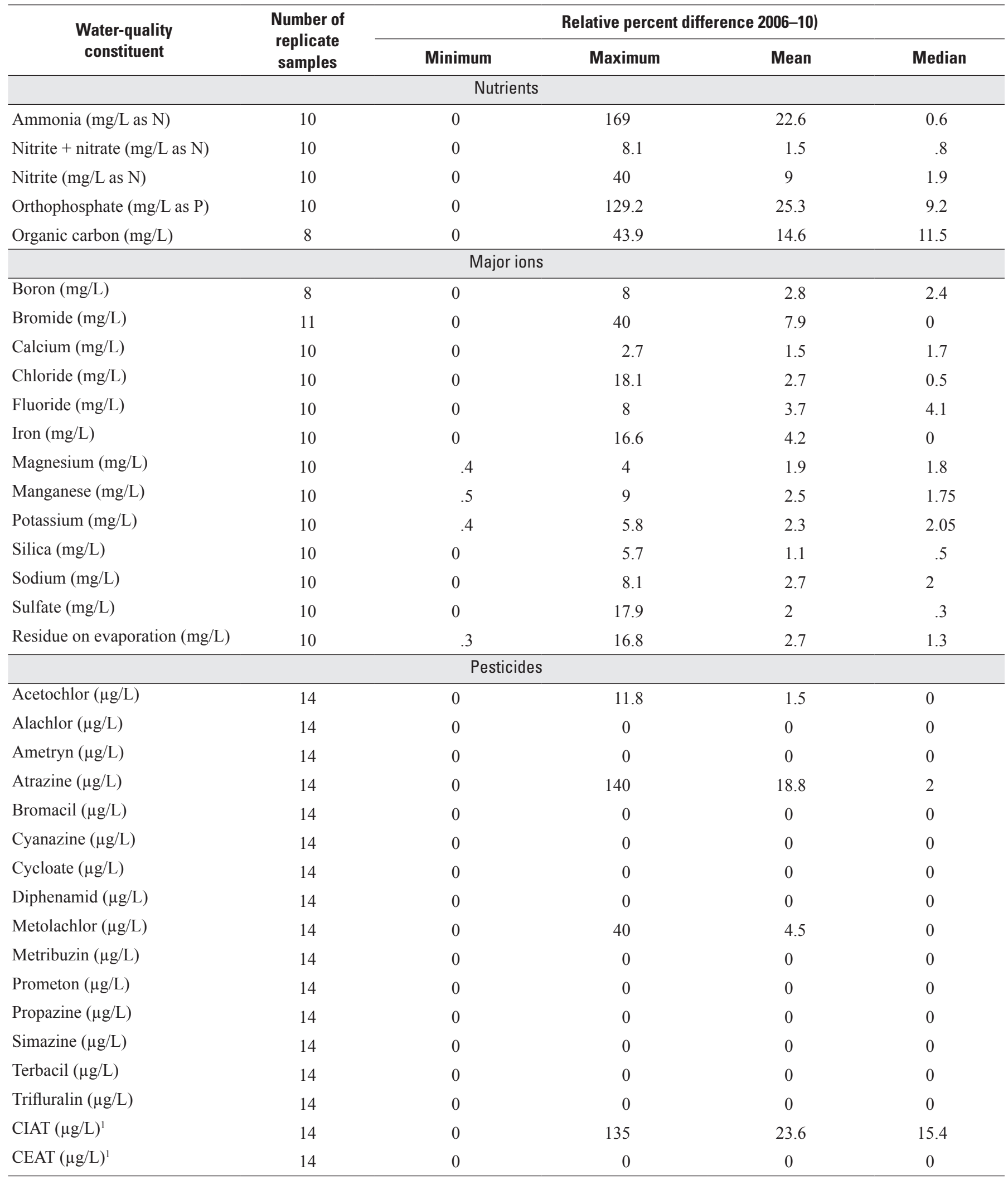

\footnotetext{
${ }^{1}$ Atrazine degradates: 2-Chloro-4-amino-6-isopropyl-amino-s-triazine (CIAT) and 2-Chloro-4-ethylamino-6-amino-s-triazine (CEAT).
} 
Table 6. Surrogate pesticide data for groundwater and surface-water samples with minimum, maximum, median, and mean percent recovery, Cedar Rapids, lowa, calendar years 2006-10.

\begin{tabular}{lcccc}
\hline \multicolumn{1}{c}{ Site name } & Minimum & Maximum & Median & Mean \\
\hline CRM-3 & Alpha-HCH-d6 surrogate & (percent recovery) & & \\
CRM-4 & 60.5 & 102 & 80.9 & 83.3 \\
CRM-4A & 71.3 & 78.5 & 74.9 & 74.9 \\
CRM-22 & 79.2 & 91.7 & 84.3 & 84.9 \\
CRM-23 & 63.1 & 101 & 80.1 & 81.6 \\
Ranney 1 & 65.1 & 122 & 83.5 & 83.5 \\
Ranney 2 & 71.0 & 102 & 84.8 & 85.6 \\
West Ranney 3 & 66.1 & 104 & 80.8 & 81.7 \\
Seminole Ranney 4 & 63.7 & 108 & 81.3 \\
Seminole 17 & 64.2 & 95.1 & 82.7 & 83.6 \\
Seminole 18 & 67.6 & 99.3 & 80.6 & 80.8 \\
Cedar Rapids Waterworks & 64.7 & 103 & 83.5 & 80.0 \\
Cedar River at Edgewood Road & 65.9 & 96.1 & 80.7 & 84.8 \\
\hline & 67.2 & 110 & 80.3 & 88.3 \\
\hline CRM-3 & Diazinon-d10 surrogate (percent recovery) & & 74.5 \\
CRM-4 & 54.5 & 130 & 87.7 & 87.6 \\
CRM-4A & 67.4 & 81.6 & 74.5 & 85.9 \\
CRM-22 & 64 & 106 & 90.2 & 86.3 \\
CRM-23 & 56.8 & 101 & 87.5 \\
Ranney 1 & 57.8 & 147 & 87.1 & 83.7 \\
Ranney 2 & 59.7 & 127 & 80.3 & 83.5 \\
West Ranney 3 & 57.9 & 126 & 85.7 & 86.7 \\
Seminole Ranney 4 & 48.5 & 112 & 82.2 & 81.9 \\
Seminole 17 & 55.4 & 119 & 85.9 & \\
Seminole 18 & 62.8 & 111 & \\
Cedar Rapids Waterworks & 54.2 & 126 & \\
Cedar River at Edgewood Road & 41.8 & 106 & \\
\hline
\end{tabular}

\section{References Cited}

Boyd, R.A., 1998, Characterizing groundwater flow in the municipal well fields of Cedar Rapids, Iowa, with selected environmental tracers: Journal of the American Water Resources Association, v. 34, no. 3, p. 507-518.

Boyd, R.A., 1999, Herbicides and herbicide degradates in shallow ground water and the Cedar River near a municipal well field, Cedar Rapids, Iowa: The Science of the Total Environment, v. 248, p. 241-253.
Boyd, R.A., Kuzniar, R.L., and Schulmeyer, P.M., 1999, Selected hydrologic data from the Cedar Rapids area, Linn County, Iowa, April 1996 through March 1999: U.S. Geological Survey Open-File Report 99-461, 214 p.

Hansen, R.E., 1970, Geology and groundwater resources of Linn County, Iowa: Iowa Geological Survey, Water-Supply Bulletin no. 10, 66 p.

Iowa Department of Natural Resources, 1994, Water-quality in Iowa during 1992 and 1993: Iowa Environmental Protection Division, Water Resources Section 305(b) Report, 226 p. 
Iowa State University, 2011, Iowa Environmental Mesonet: Annual precipitation report for climate station [IA1319] Cedar-Rapids-1, accessed April 2011 at http://mesonet. agron.iastate.edu/climodat/.

Kolpin, D.W., Thurman, E.M., and Linhart, S.M., 2000, Finding minimal herbicide concentrations in ground water? Try looking for degradates: The Science of the Total Environment, v. 248, p. 115-122.

Kolpin, D.W., Schnoebelen, D.J., and Thurman, E.M., 2004, Degradates provide insight to spatial and temporal trends of herbicides in ground water: Ground Water, v. 42, no. 4, p. 601-608.

Littin, G.R., and Schnoebelen, D.J., 2010, Selected waterquality data from the Cedar River and Cedar Rapids well fields, Cedar Rapids, Iowa, 1999-2005: U.S. Geological Survey, Data Series 494, 52 p.

Mueller, D.K., Martin, J.D., and Lopes, T.J., 1997, Qualitycontrol design for surface-water sampling in the National Water-Quality Assessment Program: U.S. Geological Survey Open-File Report 97-223, 17 p.

Oblinger-Childress, C.J., Foreman,W.T., Connor, B.F., and Maloney, T.J., 1999, New reporting procedures based on long-term method detection levels and some considerations for interpretations of water-quality data provided by the U.S. Geological Survey National Water Quality Laboratory, U.S. Geological Survey Open-File Report 99-193, 19 p.

Schnoebelen, D.J., Kalkhoff, S.J., Becher, K.D., and Thurman, E.M., 2003, Water-quality assessment of the Iowa Basins: Selected pesticides and pesticide degradates in streams, 1996-98: U.S. Geological Survey Water Resources Investigations Report 03-4075, 62 p.

Schnoebelen, D.J., and Schulmeyer, P.M., 1996, Selected hydrogeologic data from the Cedar Rapids area, Benton and Linn Counties, Iowa, October 1992 through March 1996: U.S. Geological Survey Open-File Report 96-471, 172 p.

Schulmeyer, P.M., 1995, Effect of the Cedar River on the quality of ground-water supply for Cedar Rapids, Iowa: U.S. Geological Survey Water-Resources Investigations Report 94-4211, 68 p.
Schulmeyer, P.M. and Schnoebelen, D.J., 1998, Hydrogeology and water quality in the Cedar Rapids area, Iowa, 1992-96: U.S. Geological Survey Water-Resources Investigations Report 97-4261, 77 p.

Turco, M.J., and Buchmiller, R.C., 2004, Simulation of ground-water flow in the Cedar River alluvial aquifer flow system, Cedar Rapids, Iowa: U.S. Geological Survey Scientific Investigations Report 2004-5130, 39 p.

U.S. Census Bureau, 2011, News Release-Thursday, February 10, 2011: accessed May 2011, at http://2010.census.gov/ news/releases/operations/cb11-cn24.html.

U.S. Environmental Protection Agency, 2007, Total Maximum Daily Load (TMDL) and impaired waters: U. S. Environmental Protection Agency, Region 7, TMDL/Impaired Waters, accessed November 2011, at http://www.epa.gov/ region07/water/tmdl.htm.

U.S. Geological Survey, 2006, and other chapters, variously dated, National field manual for the collection of waterquality data: U.S. Geological Survey Techniques of WaterResources Investigations, book 9, chaps. A1-A9, accessed April 2007, at http://pubs.water.usgs.gov/twri9A.

U.S. Geological Survey, 2011, Water-resources data for the United States, water year 2010: U.S. Geological Survey Water-Data Report WDR-US-20107, accessed April 2011, at http://wdr.water.usgs.gov/.

Wahl, K.D., and Bunker, B.J., 1986, Hydrology and carbonate aquifers in southwestern Linn County and adjacent parts of Benton, Iowa, and Johnson Counties, Iowa: Iowa Geological Survey, Water Supply Bulletin, no. 15, 56 p.

Wershaw, R.L., Fishman, M.J., Grabbe, R.R., and Lowe, L.E., eds., 1987, Methods for the determination of organic substances in water and fluvial sediments: U.S. Geological Survey Techniques of Water-Resources Investigations, book 5, chap. A3, 80 p. 
Tables 7-19 
Table 7. Summary statistics for physical characteristics of groundwater and surface-water samples, for all sites combined, Cedar Rapids, lowa, calendar years 2006-10.

[Numbers in parentheses indicate parameter codes; $\mathrm{mm} \mathrm{Hg}$, millimeters mercury; mg/L milligrams per liter; $\mathrm{w}$, water; $\mathrm{u}, \mathrm{unfiltered} ; \mu \mathrm{S} / \mathrm{cm}, \mathrm{microsiemens} \mathrm{per}$ centimeter at 25 degrees Celsius; ${ }^{\circ} \mathrm{C}$, degrees Celsius; $\mathrm{CaCO}_{3}$, calcium carbonate]

\begin{tabular}{|c|c|c|c|c|c|c|c|c|c|}
\hline & $\begin{array}{c}\text { Air } \\
\text { pressure } \\
(00025) \\
(\mathrm{mm} \mathrm{Hg})\end{array}$ & $\begin{array}{c}\text { Dissolved } \\
\text { oxygen }^{1} \\
(00300) \\
(\mathrm{mg} / \mathrm{L})\end{array}$ & $\begin{array}{c}\text { pH, } \\
\text { field }^{2} \\
\text { (00400) } \\
\text { (standard } \\
\text { units) } \\
\end{array}$ & $\begin{array}{c}\text { pH, } \\
\text { wu, lab } \\
\text { (00403) } \\
\text { (standard } \\
\text { units) } \\
\end{array}$ & $\begin{array}{c}\text { Specific } \\
\text { conductance, } \\
\text { field }^{3} \\
(00095) \\
(\mu \mathrm{S} / \mathrm{cm}) \\
\end{array}$ & $\begin{array}{c}\text { Specific } \\
\text { conductance, } \\
\text { lab } \\
(90095) \\
(\mu \mathrm{S} / \mathrm{cm}) \\
\end{array}$ & $\begin{array}{c}\text { Water } \\
\text { temperature } \\
(00010) \\
\left({ }^{\circ} \mathrm{C}\right)\end{array}$ & $\begin{array}{c}\text { Air } \\
\text { temperature } \\
(00020) \\
\left({ }^{\circ} \mathrm{C}\right)\end{array}$ & $\begin{array}{c}\text { Alkalinity } \\
\text { (39086) } \\
\text { (mg/L as } \\
\left.\mathrm{CaCO}_{3}\right)\end{array}$ \\
\hline Number of samples: & 95 & 152 & 162 & 162 & 170 & 161 & 162 & 66 & 164 \\
\hline Maximum: & 752 & 16.3 & 8.8 & 9 & 638 & 652 & 26.1 & 32.5 & 425 \\
\hline Mean: & 743 & 3.4 & 7.4 & 7.7 & 537 & 548 & 13.1 & 17.1 & 199 \\
\hline
\end{tabular}

Table 8. Summary statistics for physical characteristics of groundwater and surface-water samples, by site, Cedar Rapids, lowa, calendar years 2006-10.

[Numbers in parentheses indicate parameter codes; $\mathrm{mm} \mathrm{Hg}$, millimeters mercury; $\mathrm{mg} / \mathrm{L}$ milligrams per liter; w, water; $\mathrm{u}$, unfiltered; $\mu \mathrm{S} / \mathrm{cm}$, microsiemens per centimeter at 25 degress Celsius; ${ }^{\circ} \mathrm{C}$, degrees Celsius; $\mathrm{CaCO}_{3}$, calcium carbonate; na, not applicable]

\begin{tabular}{|c|c|c|c|c|}
\hline & $\begin{array}{c}\text { Air pressure } \\
\text { (00025) } \\
(\mathrm{mm} \mathrm{Hg})\end{array}$ & $\begin{array}{c}\text { Dissolved oxygen } \\
(00300) \\
(\mathrm{mg} / \mathrm{L})\end{array}$ & $\begin{array}{c}\mathrm{pH} \\
(00400) \\
\text { (standard units) }\end{array}$ & $\begin{array}{c}\text { pH, } \\
\text { wu, lab } \\
\text { (00403) } \\
\text { (standard units) }\end{array}$ \\
\hline \multicolumn{5}{|c|}{ 1993USGS CRM-3 } \\
\hline Number of samples: & 6 & 6 & 7 & 6 \\
\hline Maximum: & 751 & 2.9 & 7.5 & 7.7 \\
\hline Minimum: & 740 & .1 & 6.9 & 7.6 \\
\hline Mean: & 744 & .8 & 7.3 & 7.7 \\
\hline \multicolumn{5}{|c|}{ 1993USGS CRM-4 } \\
\hline Number of samples: & 1 & 2 & 2 & 2 \\
\hline Maximum: & 751 & 8.6 & 7.3 & 7.6 \\
\hline Minimum: & 751 & 6.2 & 7.2 & 7.6 \\
\hline Mean: & 751 & 7.4 & 7.2 & 7.6 \\
\hline \multicolumn{5}{|c|}{ 2010USGS CRM-4A } \\
\hline Number of samples: & 2 & 4 & 4 & 4 \\
\hline Maximum: & 745 & 6.4 & 7.6 & 8 \\
\hline Minimum: & 735 & .1 & 7.1 & 7.5 \\
\hline Mean: & 740 & 1.8 & 7.3 & 7.7 \\
\hline \multicolumn{5}{|c|}{ 1993USGS CRM-22 } \\
\hline Number of samples: & 8 & 12 & 15 & 17 \\
\hline Maximum: & 751 & 9 & 7.9 & 8.2 \\
\hline Minimum: & 732 & .1 & 7 & 6.2 \\
\hline Mean: & 744 & 1.9 & 7.5 & 7.7 \\
\hline \multicolumn{5}{|c|}{ 1998USGS CRM-23 } \\
\hline Number of samples: & 3 & 3 & 3 & 4 \\
\hline Maximum: & 747 & .7 & 7.3 & 7.5 \\
\hline Minimum: & 744 & .5 & 6.7 & 7.3 \\
\hline Mean: & 745 & .6 & 6.9 & 7.4 \\
\hline
\end{tabular}


Table 8. Summary statistics for physical characteristics of groundwater and surface-water samples, by site, Cedar Rapids, lowa, calendar years 2006-10.-Continued

[Numbers in parentheses indicate parameter codes; mm Hg, millimeters mercury; mg/L milligrams per liter; w, water; $\mathrm{u}$, unfiltered; $\mu \mathrm{S} / \mathrm{cm}$, microsiemens per centimeter at 25 degress Celsius; ${ }^{\circ} \mathrm{C}$, degrees Celsius; $\mathrm{CaCO}_{3}$, calcium carbonate; na, not applicable]

\begin{tabular}{|c|c|c|c|c|}
\hline & $\begin{array}{c}\text { Air pressure } \\
\text { (00025) } \\
(\mathrm{mm} \mathrm{Hg})\end{array}$ & $\begin{array}{c}\text { Dissolved oxygen } \\
(00300) \\
(\mathrm{mg} / \mathrm{L})\end{array}$ & $\begin{array}{c}\mathrm{pH} \\
(00400) \\
\text { (standard units) }\end{array}$ & $\begin{array}{c}\text { pH, } \\
\text { wu, lab } \\
\text { (00403) } \\
\text { (standard units) }\end{array}$ \\
\hline \multicolumn{5}{|c|}{ Ranney 1} \\
\hline Number of samples: & 9 & 16 & 17 & 17 \\
\hline Maximum: & 748 & 7.1 & 7.5 & 7.7 \\
\hline Minimum: & 734 & .5 & 6.6 & 7.5 \\
\hline Average: & 742 & 3.8 & 7.2 & 7.6 \\
\hline \multicolumn{5}{|c|}{ Ranney 2} \\
\hline Number of samples: & 8 & 16 & 16 & 18 \\
\hline Maximum: & 752 & 8.7 & 7.6 & 7.8 \\
\hline Minimum: & 734 & .2 & 6.9 & 7.5 \\
\hline Average: & 743 & 3.8 & 7.4 & 7.7 \\
\hline \multicolumn{5}{|c|}{ West Ranney 3} \\
\hline Number of samples: & 9 & 16 & 17 & 16 \\
\hline Maximum: & 748 & 7.7 & 7.6 & 7.9 \\
\hline Minimum: & 735 & .3 & 6.8 & 7.4 \\
\hline Average: & 741 & 2.6 & 7.3 & 7.6 \\
\hline \multicolumn{5}{|c|}{ Seminole Ranney 4} \\
\hline Number of samples: & 8 & 15 & 15 & 15 \\
\hline Maximum: & 747 & 9.7 & 7.5 & 8 \\
\hline Minimum: & 735 & .3 & 6.6 & 7.4 \\
\hline Average: & 742 & 3.1 & 8.6 & 7.6 \\
\hline \multicolumn{5}{|c|}{ Seminole 17} \\
\hline Number of samples: & 11 & 13 & 14 & 14 \\
\hline Maximum: & 750 & 7 & 7.4 & 7.7 \\
\hline Minimum: & 735 & .3 & 6.6 & 7 \\
\hline Average: & 744 & 1.8 & 7.2 & 7.6 \\
\hline \multicolumn{5}{|c|}{ Seminole 18} \\
\hline Number of samples: & 8 & 14 & 15 & 15 \\
\hline Maximum: & 748 & 6.7 & 7.4 & 8 \\
\hline Minimum: & 735 & .2 & 6.7 & 7.5 \\
\hline Average: & 744 & 1.7 & 7.2 & 7.6 \\
\hline \multicolumn{5}{|c|}{ Cedar Rapids Waterworks } \\
\hline Number of samples: & 10 & 17 & 19 & 17 \\
\hline Maximum: & 746 & 4 & 7.3 & 8.1 \\
\hline Minimum: & 727 & .1 & 6.8 & 7.1 \\
\hline Average: & 740 & 1.2 & 7.2 & 7.6 \\
\hline \multicolumn{5}{|c|}{ Cedar River at Edgewood Road } \\
\hline Number of samples: & 12 & 18 & 18 & 17 \\
\hline Maximum: & 751 & 16.3 & 8.8 & 9 \\
\hline Minimum: & 737 & 5.3 & 7.3 & 7.4 \\
\hline Average: & 744 & 11 & 8.2 & 8.2 \\
\hline
\end{tabular}


Table 9. Summary statistics for major ions in groundwater and surface-water samples, for all sites combined, Cedar Rapids, Iowa, calendar years 2006-10.

[Concentrations are in milligrams per liter unless otherwise indicated; $<$, actual value is known to be less than value shown]

\begin{tabular}{lcccc}
\hline \multicolumn{1}{c}{$\begin{array}{c}\text { Major } \\
\text { ion }\end{array}$} & $\begin{array}{c}\text { Number } \\
\text { of } \\
\text { samples }\end{array}$ & $\begin{array}{c}\text { Maximum } \\
\text { concentration }\end{array}$ & $\begin{array}{c}\text { Minimum } \\
\text { concentration }\end{array}$ & Mean \\
\hline Calcium & 160 & 85.9 & 25.1 & 70.4 \\
Magnesium & 160 & 33 & 14.9 & 21.2 \\
Potassium & 160 & 4.18 & 1.43 & 2.33 \\
Sodium & 160 & 17.8 & 5.01 & 10.5 \\
Bromide & 165 & .07 & .01 & .03 \\
Chloride & 160 & 33.3 & 15.1 & 23.4 \\
Fluoride & 160 & .35 & .13 & .23 \\
Silica & 160 & 15.6 & .18 & 10.6 \\
Sulfate & 160 & 43.3 & 17.1 & 29.3 \\
Boron $^{1}$ & 159 & 43 & 9.2 & 24.5 \\
Iron $^{1}$ & 160 & 558 & $<10$ & 46 \\
Manganese $^{1}$ & 159 & 2,060 & $<3$ & 190 \\
\hline
\end{tabular}

${ }^{1}$ Concentrations in micrograms per liter.
Table 10. Summary statistics for major ions in groundwater and surface-water samples, Cedar Rapids, Iowa, calendar years 2006-10.

[Concentrations are in milligrams per liter unless otherwise indicated; $<$, actual value is known to be less than value shown]

\begin{tabular}{|c|c|c|c|c|}
\hline $\begin{array}{l}\text { Major } \\
\text { ion }\end{array}$ & $\begin{array}{c}\text { Number } \\
\text { of } \\
\text { samples }\end{array}$ & $\begin{array}{c}\text { Maximum } \\
\text { concentration }\end{array}$ & $\begin{array}{c}\text { Minimum } \\
\text { concentration }\end{array}$ & Mean \\
\hline \multicolumn{5}{|c|}{ Groundwater } \\
\hline Calcium & 143 & 85.9 & 43.5 & 71.3 \\
\hline Magnesium & 143 & 33 & 14.9 & 21.3 \\
\hline Potassium & 143 & 3.26 & 1.43 & 2.33 \\
\hline Sodium & 143 & 17.8 & 6.8 & 10.6 \\
\hline Bromide & 149 & .06 & .01 & .03 \\
\hline Chloride & 143 & 33.3 & 15.1 & 23.5 \\
\hline Fluoride & 143 & .35 & .13 & .23 \\
\hline Silica & 143 & 15.6 & 6.21 & 10.9 \\
\hline Sulfate & 143 & 43.3 & 17.7 & 29.4 \\
\hline Boron $^{1}$ & 143 & 43 & 9.2 & 24.7 \\
\hline Iron $^{1}$ & 143 & 558 & $<10$ & 51 \\
\hline Manganese $^{1}$ & 142 & 2,060 & $<3$ & 208 \\
\hline \multicolumn{5}{|c|}{ Surface water } \\
\hline Calcium & 17 & 82.9 & 25.1 & 63.3 \\
\hline Magnesium & 17 & 25 & 15.2 & 20.6 \\
\hline Potassium & 17 & 4.18 & 1.49 & 2.3 \\
\hline Sodium & 17 & 14.2 & 5 & 9.7 \\
\hline Bromide & 16 & .07 & .02 & .04 \\
\hline Chloride & 17 & 28.4 & 15.8 & 22.2 \\
\hline Fluoride & 17 & .29 & .18 & .22 \\
\hline Silica & 17 & 14 & .18 & 8.16 \\
\hline Sulfate & 17 & 36.3 & 17.1 & 27.8 \\
\hline Boron $^{1}$ & 16 & 37 & 14 & 23 \\
\hline Iron $^{1}$ & 17 & 20 & $<10$ & 8 \\
\hline Manganese $^{1}$ & 17 & 14.5 & $<3$ & 4.7 \\
\hline
\end{tabular}


Table 11. Summary statistics for nutrients in groundwater and surface-water samples, for all sites combined, Cedar Rapids, lowa, calendar years 2006-10.

$\left[\mathrm{mg} / \mathrm{L}\right.$, milligrams per liter; $\mathrm{NH}_{3}+$ orgN, ammonia plus organic nitrogen; $\mathrm{w}$, water; f, filtered; u, unfiltered; <, less than; $\mathrm{NO}_{2}+\mathrm{NO}_{3}$, nitrite plus nitrate; $\mathrm{E}$, estimated]

\begin{tabular}{lcccc}
\hline \multicolumn{1}{c}{ Nutrient } & $\begin{array}{c}\text { Number } \\
\text { of } \\
\text { samples }\end{array}$ & $\begin{array}{c}\text { Maximum } \\
\text { concentration } \\
\text { (mg/L) }\end{array}$ & $\begin{array}{c}\text { Minimum } \\
\text { concentration } \\
\text { (mg/L) }\end{array}$ & $\begin{array}{c}\text { Average } \\
\text { (mg/L) }\end{array}$ \\
\hline $\mathrm{NH}_{3}+$ orgN, wf & 1 & 0.33 & 0.33 & 0.33 \\
$\mathrm{NH}_{3}+$ orgN, wu & 1 & 1.5 & 1.5 & 1.5 \\
$\mathrm{Ammonia}$ & 169 & 4 & $<.02$ & .14 \\
$\mathrm{NO}_{2}+\mathrm{NO}_{3}$ & 169 & 10.5 & $\mathrm{E} .02$ & 5 \\
$\mathrm{Nitrite}$ & 169 & 4 & $<.02$ & .04 \\
Orthophosphate & 169 & 4 & $\mathrm{E} .003$ & .089 \\
Phosphorus, wf & 1 & .007 & .007 & .007 \\
Phosphorus, wu & 1 & .136 & .136 & .136 \\
Organic carbon & 157 & 6 & 1.3 & 2 \\
\hline
\end{tabular}

Table 12. Summary statistics for nutrients in groundwater and surface-water samples, Cedar Rapids, lowa, calendar years 2006-10.

$\left[\mathrm{mg} / \mathrm{L}\right.$, milligrams per liter; $\mathrm{NH}_{3}+$ orgN, ammonia plus organic nitrogen; $\mathrm{w}$, water; f, filtered; --, no data; $\mathrm{u}$, unfiltered; $<$, less than; $\mathrm{NO}_{2}+\mathrm{NO}_{3}$, nitrite plus nitrate; E, estimated]

\begin{tabular}{|c|c|c|c|c|}
\hline Nutrient & $\begin{array}{c}\text { Number } \\
\text { of } \\
\text { samples }\end{array}$ & $\begin{array}{c}\text { Maximum } \\
\text { concentration } \\
\text { (mg/L) }\end{array}$ & $\begin{array}{c}\text { Minimum } \\
\text { concentration } \\
\text { (mg/L) }\end{array}$ & $\begin{array}{c}\text { Average } \\
\text { (mg/L) }\end{array}$ \\
\hline \multicolumn{5}{|c|}{ Groundwater } \\
\hline $\mathrm{NH}_{3}+\operatorname{orgN}, \mathrm{wf}$ & -- & -- & -- & -- \\
\hline $\mathrm{NH}_{3}+\operatorname{orgN}, \mathrm{wu}$ & -- & -- & -- & -- \\
\hline Ammonia & 146 & 1.75 & $<0.01$ & 0.12 \\
\hline $\mathrm{NO}_{2}+\mathrm{NO}_{3}$ & 146 & 10.5 & E.02 & 4.9 \\
\hline Nitrite & 146 & .091 & $<.001$ & .011 \\
\hline Orthophosphate & 146 & .25 & $<.01$ & .06 \\
\hline Phosphorus, wf & -- & -- & -- & -- \\
\hline Phosphorus, wu & -- & -- & -- & -- \\
\hline Organic carbon & 136 & 3.3 & 1.3 & 1.8 \\
\hline \multicolumn{5}{|c|}{ Surface water } \\
\hline $\mathrm{NH}_{3}+$ orgN, wf & 1 & 0.33 & 0.33 & 0.33 \\
\hline $\mathrm{NH}_{3}+\operatorname{orgN}$, wu & 1 & 1.5 & 1.5 & 1.5 \\
\hline Ammonia & 18 & .336 & $<.01$ & E.047 \\
\hline $\mathrm{NO}_{2}+\mathrm{NO}_{3}$ & 18 & 10.1 & .97 & 6.24 \\
\hline Nitrite & 18 & .045 & .008 & .019 \\
\hline Orthophosphate & 18 & .201 & E.003 & E.067 \\
\hline Phosphorus, wf & 1 & .007 & .007 & .007 \\
\hline Phosphorus, wu & 1 & .136 & .136 & .136 \\
\hline Organic carbon & 16 & 6 & 2 & 3.1 \\
\hline
\end{tabular}


Table 13. Summary statistics for major ions and nutrients in groundwater and surface-water samples, by site, Cedar Rapids, lowa, calendar years 2006-10.

[Concentrations are in milligrams per liter unless otherwise indicated; <, actual value is known to be less than value shown; E, estimated; $\mathrm{NH}_{3}+$ orgN, ammonia plus organic nitrogen; w, water; f, filtered; u, unfiltered; --, no data; $\mathrm{NO}_{2}+\mathrm{NO}_{3}$, nitrite plus nitrate]

\begin{tabular}{|c|c|c|c|c|}
\hline Constituent & $\begin{array}{l}\text { Number of } \\
\text { samples }\end{array}$ & $\begin{array}{c}\text { Maximum } \\
\text { concentration }\end{array}$ & $\begin{array}{c}\text { Minimum } \\
\text { concentration }\end{array}$ & Average \\
\hline \multicolumn{5}{|c|}{ 1993USGS CRM-3 } \\
\hline Calcium & 6 & 75.4 & 55.7 & 66.5 \\
\hline Magnesium & 6 & 29.1 & 20.4 & 23.6 \\
\hline Potassium & 6 & 2.84 & 1.63 & 2.09 \\
\hline Sodium & 6 & 14.4 & 8.6 & 11.4 \\
\hline Bromide & 7 & .03 & $<.02$ & E.02 \\
\hline Chloride & 6 & 33.3 & 17.4 & 24.9 \\
\hline Fluoride & 6 & .35 & .26 & .29 \\
\hline Silica & 6 & 8.42 & 6.21 & 7.43 \\
\hline Sulfate & 6 & 39 & 21.6 & 32 \\
\hline Boron $^{1}$ & 6 & 35 & 9.9 & 19 \\
\hline Iron $^{1}$ & 6 & 43 & $<8$ & E11 \\
\hline Manganese $^{1}$ & 6 & 1,220 & 484 & 855 \\
\hline $\mathrm{NH}_{3}+$ orgN, wf & -- & -- & -- & -- \\
\hline $\mathrm{NH}_{3}+\operatorname{orgN}, \mathrm{wu}$ & -- & -- & -- & -- \\
\hline Ammonia & 7 & $<.02$ & $<.02$ & $<.02$ \\
\hline $\mathrm{NO}_{2}+\mathrm{NO}_{3}$ & 7 & 7.4 & E.02 & E5 \\
\hline Nitrite & 7 & .052 & $<.002$ & E.035 \\
\hline Orthophosphate & 7 & E.023 & .011 & E.014 \\
\hline Phosphorus, wf & -- & -- & -- & -- \\
\hline Phosphorus, wu & -- & -- & -- & -- \\
\hline Organic carbon & 6 & 2.3 & 1.3 & 1.7 \\
\hline \multicolumn{5}{|c|}{ 1993USGS CRM-4 } \\
\hline Calcium & 2 & 75.2 & 74.3 & 74.8 \\
\hline Magnesium & 2 & 25.5 & 24.6 & 25.1 \\
\hline Potassium & 2 & 3.26 & 2.13 & 2.7 \\
\hline Sodium & 2 & 11.9 & 8.2 & 10 \\
\hline Bromide & 2 & .03 & .03 & .03 \\
\hline Chloride & 2 & 31.3 & 21 & 26.2 \\
\hline Fluoride & 2 & .29 & .14 & .22 \\
\hline Silica & 2 & 10.8 & 6.7 & 8.8 \\
\hline Sulfate & 2 & 34.7 & 28.6 & 31.7 \\
\hline Boron $^{1}$ & 2 & 21 & 14 & 18 \\
\hline Iron $^{1}$ & 2 & $<8$ & $<8$ & $<8$ \\
\hline Manganese $^{1}$ & 2 & 377 & $<.05$ & 189 \\
\hline $\mathrm{NH}_{3}+\operatorname{orgN}, \mathrm{wf}$ & -- & -- & -- & -- \\
\hline $\mathrm{NH}_{3}+\operatorname{orgN}, \mathrm{wu}$ & -- & -- & -- & -- \\
\hline Ammonia & 2 & E.013 & $<.02$ & E.012 \\
\hline
\end{tabular}


Table 13. Summary statistics for major ions and nutrients in groundwater and surface-water samples, by site, Cedar Rapids, lowa, calendar years 2006-10.-Continued

[Concentrations are in milligrams per liter unless otherwise indicated; <, actual value is known to be less than value shown; E, estimated; $\mathrm{NH}_{3}+\operatorname{orgN}$, ammonia plus organic nitrogen; w, water; f, filtered; u, unfiltered; --, no data; $\mathrm{NO}_{2}+\mathrm{NO}_{3}$, nitrite plus nitrate]

\begin{tabular}{|c|c|c|c|c|}
\hline Constituent & $\begin{array}{l}\text { Number of } \\
\text { samples }\end{array}$ & $\begin{array}{c}\text { Maximum } \\
\text { concentration }\end{array}$ & $\begin{array}{c}\text { Minimum } \\
\text { concentration }\end{array}$ & Average \\
\hline \multicolumn{5}{|c|}{ 1993USGS CRM-4-Continued } \\
\hline $\mathrm{NO}_{2}+\mathrm{NO}_{3}$ & 2 & 7.23 & 6.86 & 7.05 \\
\hline Nitrite & 2 & .067 & $<.02$ & E.039 \\
\hline Orthophosphate & 2 & .087 & .058 & .073 \\
\hline Phosphorus, wf & -- & -- & -- & -- \\
\hline Phosphorus, wu & -- & -- & -- & -- \\
\hline Organic carbon & 1 & 1.4 & 1.4 & 1.4 \\
\hline \multicolumn{5}{|c|}{ 2009USGS CRM-4A } \\
\hline Calcium & 4 & 70.5 & 53.5 & 61.6 \\
\hline Magnesium & 4 & 25.9 & 14.9 & 19.4 \\
\hline Potassium & 4 & 2.76 & 2 & 2.48 \\
\hline Sodium & 4 & 9.1 & 6.9 & 8.1 \\
\hline Bromide & 4 & .04 & $<.03$ & .03 \\
\hline Chloride & 4 & 22.8 & 15.1 & 18.5 \\
\hline Fluoride & 4 & .3 & .18 & .23 \\
\hline Silica & 4 & 14.5 & 10.6 & 12.6 \\
\hline Sulfate & 4 & 31.3 & 17.7 & 23.2 \\
\hline Boron $^{1}$ & 4 & 36 & 14 & 26 \\
\hline Iron $^{1}$ & 4 & 54 & 3 & 16 \\
\hline Manganese $^{1}$ & 4 & 192 & .3 & 65 \\
\hline $\mathrm{NH}_{3}+\operatorname{orgN}$, wf & -- & -- & -- & -- \\
\hline $\mathrm{NH}_{3}+\operatorname{orgN}, \mathrm{wu}$ & -- & -- & -- & -- \\
\hline Ammonia & 4 & $<.02$ & $<.02$ & $<.02$ \\
\hline $\mathrm{NO}_{2}+\mathrm{NO}_{3}$ & 4 & 7.7 & 2.9 & 5.7 \\
\hline Nitrite & 4 & .018 & .003 & .011 \\
\hline Orthophosphate & 4 & .113 & .089 & .102 \\
\hline Phosphorus, wf & -- & -- & -- & -- \\
\hline Phosphorus, wu & -- & -- & -- & -- \\
\hline Organic carbon & 4 & 3.3 & 1.5 & 2.1 \\
\hline \multicolumn{5}{|c|}{ 1998USGS CRM-22 } \\
\hline Calcium & 16 & 79 & 43.5 & 67 \\
\hline Magnesium & 16 & 33 & 17 & 21.8 \\
\hline Potassium & 16 & 2.96 & 1.43 & 2.13 \\
\hline Sodium & 16 & 17.8 & 6.8 & 10.6 \\
\hline Bromide & 16 & .05 & .02 & .03 \\
\hline Chloride & 16 & 31.4 & 17.9 & 23.5 \\
\hline Fluoride & 16 & .3 & .13 & .24 \\
\hline Silica & 16 & 13.5 & 7.9 & 10.1 \\
\hline Sulfate & 16 & 40.7 & 20.2 & 28.2 \\
\hline
\end{tabular}


Table 13. Summary statistics for major ions and nutrients in groundwater and surface-water samples, by site, Cedar Rapids, lowa, calendar years 2006-10.-Continued

[Concentrations are in milligrams per liter unless otherwise indicated; $<$, actual value is known to be less than value shown; E, estimated; $\mathrm{NH}_{3}+\operatorname{orgN}$, ammonia plus organic nitrogen; w, water; f, filtered; u, unfiltered; --, no data; $\mathrm{NO}_{2}+\mathrm{NO}_{3}$, nitrite plus nitrate]

\begin{tabular}{|c|c|c|c|c|}
\hline Constituent & $\begin{array}{l}\text { Number of } \\
\text { samples }\end{array}$ & $\begin{array}{c}\text { Maximum } \\
\text { concentration }\end{array}$ & $\begin{array}{c}\text { Minimum } \\
\text { concentration }\end{array}$ & Average \\
\hline \multicolumn{5}{|c|}{ 1998USGS CRM-22-Continued } \\
\hline Boron $^{1}$ & 16 & 34 & 9.2 & 23 \\
\hline Iron $^{1}$ & 16 & 363 & $<3$ & 50.3 \\
\hline Manganese $^{1}$ & 16 & 2,060 & $<.2$ & 249 \\
\hline $\mathrm{NH}_{3}+\operatorname{orgN}$, wf & -- & -- & -- & -- \\
\hline $\mathrm{NH}_{3}+\operatorname{orgN}, \mathrm{wu}$ & -- & -- & -- & -- \\
\hline Ammonia & 16 & 1.75 & $<.01$ & E. 163 \\
\hline $\mathrm{NO}_{2}+\mathrm{NO}_{3}$ & 16 & 10.2 & $<.06$ & 6.39 \\
\hline Nitrite & 16 & .091 & E.001 & E.012 \\
\hline Orthophosphate & 16 & .25 & .118 & .185 \\
\hline Phosphorus, wf & -- & -- & -- & -- \\
\hline Phosphorus, wu & -- & -- & -- & -- \\
\hline Organic carbon & 16 & 2.7 & 1.6 & 2.1 \\
\hline \multicolumn{5}{|c|}{ 1998USGS CRM-23 } \\
\hline Calcium & 4 & 85.9 & 75.5 & 79.1 \\
\hline Magnesium & 4 & 24.3 & 20.1 & 21.8 \\
\hline Potassium & 4 & 2.72 & 1.84 & 2.34 \\
\hline Sodium & 4 & 12.3 & 9.1 & 11.3 \\
\hline Bromide & 4 & .05 & .03 & .04 \\
\hline Chloride & 4 & 32.4 & 23.6 & 26.7 \\
\hline Fluoride & 4 & .24 & .19 & .23 \\
\hline Silica & 4 & 13.3 & 8.53 & 11.36 \\
\hline Sulfate & 4 & 36.3 & 26.3 & 33.4 \\
\hline Boron $^{1}$ & 4 & 20 & 9.6 & 16.2 \\
\hline Iron $^{1}$ & 4 & 33 & $<6$ & 23 \\
\hline Manganese $^{1}$ & 4 & 35.3 & .8 & 21.3 \\
\hline $\mathrm{NH}_{3}+\operatorname{orgN}$, wf & -- & -- & -- & -- \\
\hline $\mathrm{NH}_{3}+\operatorname{orgN}$, wu & -- & -- & -- & -- \\
\hline Ammonia & 4 & $<.04$ & $<.01$ & E.011 \\
\hline $\mathrm{NO}_{2}+\mathrm{NO}_{3}$ & 4 & 9.7 & .7 & 4.6 \\
\hline Nitrite & 4 & .061 & $<.002$ & E.023 \\
\hline Orthophosphate & 4 & .138 & .09 & .115 \\
\hline Phosphorus, wf & -- & -- & -- & -- \\
\hline Phosphorus, wu & -- & -- & -- & -- \\
\hline Organic carbon & 4 & 2.5 & 2 & 2.3 \\
\hline
\end{tabular}


Table 13. Summary statistics for major ions and nutrients in groundwater and surface-water samples, by site, Cedar Rapids, lowa, calendar years 2006-10.-Continued

[Concentrations are in milligrams per liter unless otherwise indicated; $<$, actual value is known to be less than value shown; E, estimated; $\mathrm{NH}_{3}+$ orgN, ammonia plus organic nitrogen; w, water; f, filtered; u, unfiltered; --, no data; $\mathrm{NO}_{2}+\mathrm{NO}_{3}$, nitrite plus nitrate]

\begin{tabular}{|c|c|c|c|c|}
\hline Constituent & $\begin{array}{l}\text { Number of } \\
\text { samples }\end{array}$ & $\begin{array}{c}\text { Maximum } \\
\text { concentration }\end{array}$ & $\begin{array}{c}\text { Minimum } \\
\text { concentration }\end{array}$ & Average \\
\hline \multicolumn{5}{|c|}{ Ranney 1} \\
\hline Calcium & 17 & 81.4 & 60.1 & 73.8 \\
\hline Magnesium & 17 & 26.1 & 16.6 & 21.5 \\
\hline Potassium & 17 & 3.14 & 1.78 & 2.26 \\
\hline Sodium & 17 & 14.1 & 8.2 & 10.7 \\
\hline Bromide & 18 & .05 & .03 & .03 \\
\hline Chloride & 17 & 30.6 & 16.9 & 23.4 \\
\hline Fluoride & 17 & .3 & .17 & .22 \\
\hline Silica & 17 & 15.4 & 7.9 & 11.1 \\
\hline Sulfate & 17 & 39.4 & 21.6 & 29.9 \\
\hline Boron $^{1}$ & 17 & 33 & 17 & 24 \\
\hline Iron $^{1}$ & 17 & $<8$ & $<3$ & $<5.4$ \\
\hline Manganese $^{1}$ & 16 & 42 & 9.1 & 20.1 \\
\hline $\mathrm{NH}_{3}+\operatorname{orgN}$, wf & -- & -- & -- & -- \\
\hline $\mathrm{NH}_{3}+\operatorname{orgN}, \mathrm{wu}$ & -- & -- & -- & -- \\
\hline Ammonia & 17 & .062 & $<.02$ & E.022 \\
\hline $\mathrm{NO}_{2}+\mathrm{NO}_{3}$ & 17 & 7.63 & 1.19 & 4.77 \\
\hline Nitrite & 17 & .013 & E.001 & E.004 \\
\hline Orthophosphate & 17 & .074 & E.02 & E.041 \\
\hline Phosphorus, wf & -- & -- & -- & -- \\
\hline Phosphorus, wu & -- & -- & -- & -- \\
\hline Organic carbon & 16 & 2.3 & 1.3 & 1.7 \\
\hline \multicolumn{5}{|c|}{ Ranney 2} \\
\hline Calcium & 14 & 83.3 & 50.5 & 72.5 \\
\hline Magnesium & 14 & 25.9 & 15.2 & 21.4 \\
\hline Potassium & 14 & 3.05 & 1.78 & 2.32 \\
\hline Sodium & 14 & 14.6 & 7.9 & 10.8 \\
\hline Bromide & 14 & .05 & .03 & .04 \\
\hline Chloride & 14 & 30.3 & 17.7 & 24.4 \\
\hline Fluoride & 14 & .28 & .19 & .24 \\
\hline Silica & 14 & 13.5 & 7.5 & 10.1 \\
\hline Sulfate & 14 & 38 & 24.3 & 31.7 \\
\hline Boron $^{1}$ & 14 & 32 & 19 & 24 \\
\hline Iron $^{1}$ & 14 & 36 & $<4$ & E9 \\
\hline Manganese $^{1}$ & 14 & 35.3 & 1.4 & 12.9 \\
\hline $\mathrm{NH}_{3}+\operatorname{orgN}$, wf & -- & -- & -- & -- \\
\hline $\mathrm{NH}_{3}+\operatorname{orgN}$, wu & -- & -- & -- & -- \\
\hline
\end{tabular}


Table 13. Summary statistics for major ions and nutrients in groundwater and surface-water samples, by site, Cedar Rapids, Iowa, calendar years 2006-10.-Continued

[Concentrations are in milligrams per liter unless otherwise indicated; $<$, actual value is known to be less than value shown; E, estimated; $\mathrm{NH}_{3}+\operatorname{orgN}$, ammonia plus organic nitrogen; w, water; f, filtered; u, unfiltered; --, no data; $\mathrm{NO}_{2}+\mathrm{NO}_{3}$, nitrite plus nitrate]

\begin{tabular}{|c|c|c|c|c|}
\hline Constituent & $\begin{array}{l}\text { Number of } \\
\text { samples }\end{array}$ & $\begin{array}{c}\text { Maximum } \\
\text { concentration }\end{array}$ & $\begin{array}{c}\text { Minimum } \\
\text { concentration }\end{array}$ & Average \\
\hline \multicolumn{5}{|c|}{ Ranney 2-Continued } \\
\hline Ammonia & 17 & 0.049 & $<.01$ & E.012 \\
\hline $\mathrm{NO}_{2}+\mathrm{NO}_{3}$ & 17 & 10.5 & 1.11 & 5.9 \\
\hline Nitrite & 17 & .74 & $<.001$ & E.007 \\
\hline Orthophosphate & 17 & .234 & .042 & .074 \\
\hline Phosphorus, wf & -- & -- & -- & -- \\
\hline Phosphorus, wu & -- & -- & -- & -- \\
\hline Organic carbon & 16 & 2.1 & 1.3 & 1.7 \\
\hline \multicolumn{5}{|c|}{ West Ranney 3} \\
\hline Calcium & 16 & 79 & 64.1 & 71 \\
\hline Magnesium & 16 & 25.6 & 17.6 & 20.8 \\
\hline Potassium & 16 & 2.98 & 1.93 & 2.42 \\
\hline Sodium & 16 & 16.6 & 8 & 10.8 \\
\hline Bromide & 17 & .05 & .02 & .03 \\
\hline Chloride & 16 & 31.7 & 17.8 & 23.9 \\
\hline Fluoride & 16 & .28 & .19 & .23 \\
\hline Silica & 16 & 15.6 & 11 & 12.5 \\
\hline Sulfate & 16 & 38.2 & 22.3 & 29.1 \\
\hline Boron $^{1}$ & 16 & 34 & 18 & 24 \\
\hline Iron $^{1}$ & 16 & 159 & $<3$ & E23.5 \\
\hline Manganese $^{1}$ & 16 & 1,150 & 125 & 398 \\
\hline $\mathrm{NH}_{3}+\operatorname{orgN}$, wf & -- & -- & -- & -- \\
\hline $\mathrm{NH}_{3}+\operatorname{orgN}, \mathrm{wu}$ & -- & -- & -- & -- \\
\hline Ammonia & 16 & 1.07 & .07 & .37 \\
\hline $\mathrm{NO}_{2}+\mathrm{NO}_{3}$ & 16 & 7 & .6 & 4.3 \\
\hline Nitrite & 16 & .023 & $<.008$ & E.008 \\
\hline Orthophosphate & 16 & .079 & .03 & .055 \\
\hline Phosphorus, wf & -- & -- & -- & -- \\
\hline Phosphorus, wu & -- & -- & -- & -- \\
\hline Organic carbon & 15 & 2.3 & 1.3 & 1.8 \\
\hline \multicolumn{5}{|c|}{ Seminole Ranney 4} \\
\hline Calcium & 15 & 79.3 & 59.8 & 70.9 \\
\hline Magnesium & 15 & 26.9 & 17.2 & 20.5 \\
\hline Potassium & 15 & 2.87 & 1.56 & 2.33 \\
\hline Sodium & 15 & 13.9 & 7 & 9.9 \\
\hline Bromide & 16 & .05 & E.01 & E.03 \\
\hline Chloride & 15 & 29.9 & 16.6 & 22.7 \\
\hline Fluoride & 15 & .3 & .14 & .23 \\
\hline
\end{tabular}


Table 13. Summary statistics for major ions and nutrients in groundwater and surface-water samples, by site, Cedar Rapids, lowa, calendar years 2006-10.-Continued

[Concentrations are in milligrams per liter unless otherwise indicated; $<$, actual value is known to be less than value shown; E, estimated; $\mathrm{NH}_{3}+$ orgN, ammonia plus organic nitrogen; w, water; f, filtered; u, unfiltered; --, no data; $\mathrm{NO}_{2}+\mathrm{NO}_{3}$, nitrite plus nitrate]

\begin{tabular}{|c|c|c|c|c|}
\hline Constituent & $\begin{array}{l}\text { Number of } \\
\text { samples }\end{array}$ & $\begin{array}{c}\text { Maximum } \\
\text { concentration }\end{array}$ & $\begin{array}{c}\text { Minimum } \\
\text { concentration }\end{array}$ & Average \\
\hline \multicolumn{5}{|c|}{ Seminole Ranney 4-Continued } \\
\hline Silica & 15 & 14.1 & 8.4 & 11.3 \\
\hline Sulfate & 15 & 43.3 & 19.5 & 29.4 \\
\hline Boron $^{1}$ & 15 & 35 & 19 & 26 \\
\hline $\operatorname{Iron}^{1}$ & 15 & 7 & $<3$ & E3.4 \\
\hline Manganese $^{1}$ & 15 & 248 & 9.7 & 68.9 \\
\hline $\mathrm{NH}_{3}+$ orgN, wf & -- & -- & -- & -- \\
\hline $\mathrm{NH}_{3}+$ orgN, wu & -- & -- & -- & -- \\
\hline Ammonia & 16 & .23 & $<.02$ & E.07 \\
\hline $\mathrm{NO}_{2}+\mathrm{NO}_{3}$ & 16 & 8.6 & .8 & 5.3 \\
\hline Nitrite & 16 & .026 & E.002 & E.01 \\
\hline Orthophosphate & 16 & .076 & .04 & .058 \\
\hline Phosphorus, wf & -- & -- & -- & -- \\
\hline Phosphorus, wu & -- & -- & -- & -- \\
\hline Organic carbon & 15 & 2.1 & 1.6 & 1.8 \\
\hline \multicolumn{5}{|c|}{ Seminole 17} \\
\hline Calcium & 14 & 78.9 & 66.6 & 72 \\
\hline Magnesium & 14 & 23.6 & 18.1 & 20.7 \\
\hline Potassium & 14 & 2.97 & 1.79 & 2.38 \\
\hline Sodium & 14 & 13.3 & 8.3 & 10.5 \\
\hline Bromide & 15 & .04 & .03 & .04 \\
\hline Chloride & 14 & 28.4 & 17.9 & 23.3 \\
\hline Fluoride & 14 & .27 & .2 & .23 \\
\hline Silica & 14 & 12.8 & 8.4 & 10.3 \\
\hline Sulfate & 14 & 37.3 & 23.4 & 28.9 \\
\hline Boron $^{1}$ & 14 & 31 & 19 & 23 \\
\hline Iron $^{1}$ & 14 & 139 & E5 & E88.5 \\
\hline Manganese $^{1}$ & 14 & 402 & 135 & 274 \\
\hline $\mathrm{NH}_{3}+\operatorname{orgN}, \mathrm{wf}$ & -- & -- & -- & -- \\
\hline $\mathrm{NH}_{3}+\operatorname{orgN}$, wu & -- & -- & -- & -- \\
\hline Ammonia & 15 & .141 & .026 & .082 \\
\hline $\mathrm{NO}_{2}+\mathrm{NO}_{3}$ & 15 & 7.3 & 1.8 & 4.1 \\
\hline Nitrite & 15 & .016 & E.004 & E.008 \\
\hline Orthophosphate & 15 & .038 & E.01 & E.028 \\
\hline Phosphorus, wf & -- & -- & -- & -- \\
\hline Phosphorus, wu & -- & -- & -- & -- \\
\hline Organic carbon & 14 & 2.2 & 1.5 & 1.9 \\
\hline
\end{tabular}


Table 13. Summary statistics for major ions and nutrients in groundwater and surface-water samples, by site, Cedar Rapids, lowa, calendar years 2006-10.-Continued

[Concentrations are in milligrams per liter unless otherwise indicated; $<$, actual value is known to be less than value shown; E, estimated; $\mathrm{NH}_{3}+\operatorname{orgN}$, ammonia plus organic nitrogen; w, water; f, filtered; u, unfiltered; --, no data; $\mathrm{NO}_{2}+\mathrm{NO}_{3}$, nitrite plus nitrate]

\begin{tabular}{|c|c|c|c|c|}
\hline Constituent & $\begin{array}{l}\text { Number of } \\
\text { samples }\end{array}$ & $\begin{array}{c}\text { Maximum } \\
\text { concentration }\end{array}$ & $\begin{array}{c}\text { Minimum } \\
\text { concentration }\end{array}$ & Average \\
\hline \multicolumn{5}{|c|}{ Seminole 18} \\
\hline Calcium & 15 & 79 & 68.3 & 72.9 \\
\hline Magnesium & 15 & 27.8 & 18 & 20.8 \\
\hline Potassium & 15 & 3.02 & 1.78 & 2.43 \\
\hline Sodium & 15 & 14.6 & 7.8 & 10.2 \\
\hline Bromide & 16 & .05 & $<.02$ & E.03 \\
\hline Chloride & 15 & 30.1 & 17 & 22.4 \\
\hline Fluoride & 15 & .27 & .18 & .23 \\
\hline Silica & 15 & 13.5 & 6.2 & 10.4 \\
\hline Sulfate & 15 & 41.2 & 20.1 & 28.1 \\
\hline Boron $^{1}$ & 15 & 31 & 17 & 24 \\
\hline Iron $^{1}$ & 15 & 117 & 66 & 88 \\
\hline Manganese $^{1}$ & 15 & 431 & 79.6 & 161 \\
\hline $\mathrm{NH}_{3}+$ orgN, wf & -- & -- & -- & -- \\
\hline $\mathrm{NH}_{3}+\operatorname{orgN}, \mathrm{wu}$ & -- & -- & -- & -- \\
\hline Ammonia & 15 & .487 & E.017 & E.058 \\
\hline $\mathrm{NO}_{2}+\mathrm{NO}_{3}$ & 15 & 7.68 & 2 & 4.35 \\
\hline Nitrite & 15 & .008 & .003 & E.005 \\
\hline Orthophosphate & 15 & .034 & $<.01$ & E.022 \\
\hline Phosphorus, wf & -- & -- & -- & -- \\
\hline Phosphorus, wu & -- & -- & -- & -- \\
\hline Organic carbon & 14 & 2.3 & 1.5 & 1.8 \\
\hline \multicolumn{5}{|c|}{ Cedar Rapids Waterworks } \\
\hline Calcium & 17 & 78.1 & 66.3 & 71.9 \\
\hline Magnesium & 17 & 27.1 & 18.7 & 22.2 \\
\hline Potassium & 17 & 3.09 & 2.03 & 2.46 \\
\hline Sodium & 17 & 14.1 & 8.8 & 11.2 \\
\hline Bromide & 17 & .06 & .03 & .04 \\
\hline Chloride & 17 & 30.7 & 19.2 & 24.6 \\
\hline Fluoride & 17 & .28 & .19 & .24 \\
\hline Silica & 17 & 15 & 10.4 & 12.5 \\
\hline Sulfate & 17 & 37.8 & 24.2 & 29.8 \\
\hline Boron $^{1}$ & 17 & 43 & 21 & 33 \\
\hline Iron $^{1}$ & 17 & 558 & 8 & 179 \\
\hline Manganese $^{1}$ & 17 & 816 & 54 & 353 \\
\hline $\mathrm{NH}_{3}+\operatorname{orgN}, \mathrm{wf}$ & -- & -- & -- & -- \\
\hline $\mathrm{NH}_{3}+\operatorname{orgN}, \mathrm{wu}$ & -- & -- & -- & -- \\
\hline
\end{tabular}


Table 13. Summary statistics for major ions and nutrients in groundwater and surface-water samples, by site, Cedar Rapids, lowa, calendar years 2006-10.-Continued

[Concentrations are in milligrams per liter unless otherwise indicated; $<$, actual value is known to be less than value shown; E, estimated; $\mathrm{NH}_{3}+$ orgN, ammonia plus organic nitrogen; w, water; f, filtered; u, unfiltered; --, no data; $\mathrm{NO}_{2}+\mathrm{NO}_{3}$, nitrite plus nitrate]

\begin{tabular}{|c|c|c|c|c|}
\hline Constituent & $\begin{array}{l}\text { Number of } \\
\text { samples }\end{array}$ & $\begin{array}{c}\text { Maximum } \\
\text { concentration }\end{array}$ & $\begin{array}{c}\text { Minimum } \\
\text { concentration }\end{array}$ & Average \\
\hline \multicolumn{5}{|c|}{ Cedar Rapids Waterworks - Continued } \\
\hline Ammonia & 17 & .97 & .027 & .343 \\
\hline $\mathrm{NO}_{2}+\mathrm{NO}_{3}$ & 17 & 6 & .6 & 3.8 \\
\hline Nitrite & 17 & .07 & .005 & .019 \\
\hline Orthophosphate & 17 & .083 & .028 & .047 \\
\hline Phosphorus, wf & -- & -- & -- & -- \\
\hline Phosphorus, wu & -- & -- & -- & -- \\
\hline Organic carbon & 16 & 2.3 & 1.5 & 1.9 \\
\hline \multicolumn{5}{|c|}{ Cedar River Edgewood Road } \\
\hline Calcium & 17 & 82.9 & 25.1 & 63.3 \\
\hline Magnesium & 17 & 25 & 15.2 & 20.6 \\
\hline Potassium & 17 & 4.18 & 1.49 & 2.3 \\
\hline Sodium & 17 & 14.2 & 5 & 9.7 \\
\hline Bromide & 16 & .07 & E.02 & E.04 \\
\hline Chloride & 17 & 28.4 & 15.8 & 22.2 \\
\hline Fluoride & 17 & .29 & .18 & .23 \\
\hline Silica & 17 & 14 & .18 & 8.2 \\
\hline Sulfate & 17 & 36.3 & 17.1 & 27.8 \\
\hline Boron $^{1}$ & 16 & 37 & 14 & 23 \\
\hline Iron $^{1}$ & 17 & 20 & E2 & E8 \\
\hline Manganese $^{1}$ & 17 & 14.5 & 1.5 & 4.7 \\
\hline $\mathrm{NH}_{3}+\operatorname{orgN}, \mathrm{wf}$ & 1 & .33 & .33 & .33 \\
\hline $\mathrm{NH}_{3}+\operatorname{orgN}, \mathrm{wu}$ & 1 & 1.5 & 1.5 & 1.5 \\
\hline Ammonia & 18 & .336 & $<.01$ & E.047 \\
\hline $\mathrm{NO}_{2}+\mathrm{NO}_{3}$ & 18 & 10.1 & .97 & 6.2 \\
\hline Nitrite & 18 & .045 & .008 & .019 \\
\hline Orthophosphate & 18 & .201 & E.003 & E.067 \\
\hline Phosphorus, wf & 1 & .007 & .007 & .007 \\
\hline Phosphorus, wu & 1 & .136 & .136 & .136 \\
\hline Organic carbon & 16 & 6 & 2 & 3.1 \\
\hline
\end{tabular}

${ }^{1}$ Concentrations in micrograms per liter. 
Table 14. Description of pesticides in water-quality samples, Cedar Rapids, lowa, calendar years 2006-10.

[NWIS, National Water Information System; CASRN, Chemical Abstract Service Registry Number]

\begin{tabular}{|c|c|c|c|c|c|}
\hline $\begin{array}{l}\text { NWIS } \\
\text { code }\end{array}$ & $\begin{array}{l}\text { NWIS } \\
\text { name }\end{array}$ & Other common names ${ }^{1}$ & CASRN $^{2}$ & Use $^{3}$ & Chemical class $^{3}$ \\
\hline 46342 & Alachlor & Alanox, Lasso, Metachlor & ${ }^{3} 15972-60-8$ & Herbicide & Chloroacetanilide \\
\hline 49260 & Acetochlor & Harness, Nevirex & ${ }^{3} 34256-82-1$ & Herbicide & Chloroacetanilide \\
\hline 38401 & Ametryn & Topazol, Trinatox D & $834-12-8$ & Herbicide & Triazine \\
\hline 04029 & Bromacil & Du Pont herbicide 976, Nalkil, Rout G-8 & ${ }^{3} 314-40-9$ & Herbicide & Uracil \\
\hline 04026 & Butachlor & Machete, Weedout & $23184-66-9$ & Herbicide & Chloroacetanilide \\
\hline 04028 & Butylate & Tomahawk & $2008-41-5$ & Herbicide & Thiocarbamate \\
\hline 04031 & Cycloate & Ro-Neet, Ronit & ${ }^{3} 1134-23-2$ & Herbicide & Thiocarbamate \\
\hline 04033 & Diphenamid & Fenam, Rideon & $957-51-7$ & Herbicide & Amide \\
\hline 04025 & Hexazinone & Velpar, Pronone & ${ }^{3} 51235-04-2$ & Herbicide & Triazinone \\
\hline 39415 & Metolachlor & Dual Magnum, Pennant, Primextra & ${ }^{3} 51218-45-2$ & Herbicide & Chloroacetanilide \\
\hline 82630 & Metribuzin & Lexone, Zenkor & $21087-64-9$ & Herbicide & Triazinone \\
\hline 04037 & Prometon & Ontrack, Primatol & ${ }^{3} 1610-18-0$ & Herbicide & Triazine \\
\hline 04035 & Simazine & Azotop, Herbex, Radocon, Weedex & ${ }^{3} 122-34-9$ & Herbicide & Triazine \\
\hline 04030 & Simetryn & Gy-Bon, Simetryn & $1014-70-6$ & Herbicide & Triazine \\
\hline 82665 and 04032 & Terbacil & Sinbar, Terbacil & $5902-51-2$ & Herbicide & Uracil \\
\hline 82661 and 04023 & Trifluralin & Heritage, Trifloran, Trigard, Tristar & ${ }^{3} 1582-09-8$ & Herbicide & 2,6-Dinitroaniline \\
\hline 04034 & Vernolate & PPTC, Surpass, Vernolate & $1929-77-7$ & Herbicide & Thiocarbamate \\
\hline 04040 & CIAT $^{4}$ & Deethylatrazine (DEA) & $6190-54-4$ & Breakdown product of atrazine & Triazine \\
\hline 04038 & CEAT $^{5}$ & Deisopropylatrazine (DIA) & $1007-28-9$ & Breakdown product of atrazine & Triazine \\
\hline
\end{tabular}

${ }^{1}$ From http://www.chemindustry.com (unless otherwise noted).

${ }^{2}$ This report contains CAS Registry Numbers ${ }^{\circledR}$, which is a Registered Trademark of the American Chemical Society. CAS recommends the verification of the CASRNs through CAS Client Services ${ }^{\mathrm{SM}}$.

${ }^{3}$ From http://www.pesticideinfo.org/Index.html.

${ }^{4}$ 2-Chloro-4-isopropylamino-6-amino-s-triazine (CIAT).

${ }^{5}$ 2-Chloro-6-ethylamino-4-amino-s-triazine (CEAT). 
Table 15. Pesticides that were not detected in water-quality samples, Cedar Rapids, lowa, calendar years 2006-10.

[NWIS, National Water Inventory System; LRL, laboratory reporting level; $\mu \mathrm{g} / \mathrm{L}$, micrograms per liter]

\begin{tabular}{ccc}
\hline $\begin{array}{c}\text { NWIS } \\
\text { parameter code }\end{array}$ & $\begin{array}{c}\text { Pesticides } \\
\text { (not detected) }\end{array}$ & $\begin{array}{c}\text { LRL } \\
(\boldsymbol{\mu g} / \mathbf{L})\end{array}$ \\
\hline 38401 & Ametryn & 0.05 \\
04029 & Bromacil & .05 \\
04026 & Butachlor & .05 \\
04028 & Butylate & .05 \\
04041 & Cyanazine & .05 \\
04031 & Cycloate & .05 \\
04033 & Diphenamid & .05 \\
04025 & Hexazinone & .05 \\
04037 & Prometon & .05 \\
04036 & Prometryn & .05 \\
04024 & Propachlor & .05 \\
04032 & Terbacil & .05 \\
04023 & Trifluralin & .05 \\
04030 & Simetryn & .05 \\
04034 & Vernolate & .05 \\
\hline
\end{tabular}

Table 16. Selected pesticides detected and frequency of detections in groundwater and surface-water samples, for all sites combined, Cedar Rapids, lowa, calendar years 2006-10.

[LRL, laboratory reporting level; $\mu \mathrm{g} / \mathrm{L}$, micrograms per liter; E, estimate]

\begin{tabular}{|c|c|c|c|c|c|c|c|}
\hline \multirow{2}{*}{ Pesticide } & \multirow{2}{*}{$\begin{array}{c}\text { Number of } \\
\text { detections/ } \\
\text { samples }\end{array}$} & \multirow{2}{*}{$\begin{array}{l}\mathrm{LRL}^{1} \\
(\mu \mathrm{g} / \mathrm{L})\end{array}$} & \multirow{2}{*}{$\begin{array}{c}\text { Number of } \\
\text { detectable } \\
\text { concentrations } \\
\text { at or above LRL }\end{array}$} & \multirow{2}{*}{$\begin{array}{c}\text { Number of } \\
\text { detectable } \\
\text { concentrations } \\
\text { below LRL }\end{array}$} & \multirow{2}{*}{$\begin{array}{l}\text { Percentage of } \\
\text { samples with } \\
\text { detectable } \\
\text { concentrations }^{2}\end{array}$} & \multicolumn{2}{|c|}{$\begin{array}{l}\text { Detectable concentrations } \\
(\mu \mathrm{g} / \mathrm{L})\end{array}$} \\
\hline & & & & & & Maximum & Median \\
\hline Atrazine & $172 / 173$ & 0.05 & 161 & 11 & 99.4 & 2.17 & 0.11 \\
\hline CIAT $^{3}$ & $172 / 173$ & .05 & 172 & 0 & 99.4 & .39 & .09 \\
\hline Metolachlor & $172 / 173$ & .05 & 113 & 59 & 99.4 & .84 & .05 \\
\hline Acetochlor & $67 / 173$ & .05 & 29 & 38 & 38.7 & .88 & .04 \\
\hline${ }^{3} \mathrm{CEAT}$ & $39 / 173$ & .05 & 14 & 25 & 22.5 & .15 & .04 \\
\hline Propazine & $19 / 173$ & .05 & 0 & 19 & 10.9 & E.04 & .01 \\
\hline Alachlor & $4 / 173$ & .05 & 0 & 4 & 2.3 & E. 04 & .02 \\
\hline Simazine & $3 / 173$ & .05 & 0 & 3 & 1.7 & E. 02 & .02 \\
\hline Metribuzin & $2 / 173$ & .05 & 0 & 2 & 1.2 & E. 03 & .02 \\
\hline Carboxin & $1 / 173$ & .05 & 0 & 1 & .6 & E. 01 & .01 \\
\hline
\end{tabular}

${ }^{1}$ Highest laboratory reporting level for period of record.

${ }^{2}$ Includes both quantifiable and unquantifiable (estimated) concentrations. Quantifiable detections exist for concentrations that exceeded lower laboratory reporting levels during period of record.

${ }^{3}$ Atrazine degradates: 2-Chloro-4-amino-6-isopropyl-amino-striazine (CIAT) and 2-Chloro-4-ethylamino-6-amino-s-triazine (CEAT). 
Table 17. Selected pesticides detected and frequency of detections in groundwater and surface-water samples, Cedar Rapids, lowa, calendar years 2006-10.

[LRL, laboratory reporting level; $\mu \mathrm{g} / \mathrm{L}$, micrograms per liter; E, estimate; ND, not detected]

\begin{tabular}{|c|c|c|c|c|c|c|c|}
\hline \multirow{2}{*}{ Pesticide } & \multirow{2}{*}{$\begin{array}{l}\text { Number of } \\
\text { detections/ } \\
\text { samples }\end{array}$} & \multirow{2}{*}{$\begin{array}{l}\operatorname{LRL}^{1} \\
(\mu \mathrm{g} / \mathrm{L})\end{array}$} & \multirow{2}{*}{$\begin{array}{l}\text { Number of } \\
\text { detectable } \\
\text { concentrations } \\
\text { at or greater } \\
\text { than LRL }\end{array}$} & \multirow{2}{*}{$\begin{array}{c}\text { Number of } \\
\text { detectable } \\
\text { concentrations } \\
\text { less than } \mathrm{LRL}^{2}\end{array}$} & \multirow{2}{*}{$\begin{array}{l}\text { Percentage of } \\
\text { samples with } \\
\text { detectable } \\
\text { concentrations }\end{array}$} & \multicolumn{2}{|c|}{$\begin{array}{l}\text { Detectable concentrations } \\
(\mu \mathrm{g} / \mathrm{L})\end{array}$} \\
\hline & & & & & & Maximum & Median \\
\hline \multicolumn{8}{|c|}{ Groundwater } \\
\hline Atrazine & $155 / 156$ & 0.05 & 146 & 9 & 99.4 & 1.1 & 0.12 \\
\hline${ }^{3}$ CIAT & $155 / 156$ & .05 & 155 & 0 & 99.4 & .24 & .09 \\
\hline Metolachlor & $155 / 156$ & .05 & 99 & 56 & 99.4 & .45 & .06 \\
\hline Acetochlor & $57 / 156$ & .05 & 20 & 37 & 36.5 & .21 & E.03 \\
\hline${ }^{3} \mathrm{CEAT}$ & $36 / 156$ & .05 & 12 & 24 & 23.1 & .09 & E.04 \\
\hline Propazine & $16 / 156$ & .05 & 0 & 16 & 10.2 & E.02 & E.01 \\
\hline Alachlor & $3 / 156$ & .05 & 0 & 3 & 1.9 & E.02 & E.02 \\
\hline Simazine & $2 / 156$ & .05 & 0 & 2 & 1.3 & E.03 & E.02 \\
\hline Metribuzin & $2 / 156$ & .05 & 0 & 2 & 1.3 & E.03 & E.02 \\
\hline Carboxin & $1 / 156$ & .05 & 0 & 1 & .6 & E.02 & E.02 \\
\hline \multicolumn{8}{|c|}{ Surface water } \\
\hline Atrazine & $17 / 17$ & 0.05 & 16 & 1 & 100 & 2.17 & 0.1 \\
\hline${ }^{3}$ CIAT & $17 / 17$ & .05 & 17 & 0 & 100 & .39 & .09 \\
\hline Metolachlor & $17 / 17$ & .05 & 13 & 4 & 100 & .84 & .06 \\
\hline Acetochlor & $9 / 17$ & .05 & 8 & 1 & 52.9 & .88 & .08 \\
\hline${ }^{3} \mathrm{CEAT}$ & $4 / 16$ & .05 & 3 & 1 & 25 & .15 & .06 \\
\hline Propazine & $3 / 17$ & .05 & 0 & 3 & 17.6 & E.04 & E.02 \\
\hline Alachlor & $1 / 17$ & .05 & 0 & 1 & 5.9 & E.02 & E.02 \\
\hline Simazine & $1 / 17$ & .05 & 0 & 1 & 5.9 & E.04 & E.04 \\
\hline Metribuzin & $0 / 17$ & .05 & 0 & 0 & 0 & ND & ND \\
\hline Carboxin & $0 / 17$ & .05 & 0 & 0 & 0 & ND & ND \\
\hline
\end{tabular}

${ }^{1}$ Highest laboratory reporting level for period of record.

${ }^{2}$ Includes both quantifiable and unquantifiable (estimated) concentrations. Quantifiable detections exist for concentrations that exceeded lower laboratory reporting levels during period of record.

${ }^{3}$ Atrazine degradates: 2-Chloro-4-amino-6-isopropyl-amino-striazine (CIAT) and 2-Chloro-4-ethylamino-6-amino-s-triazine (CEAT). 
Table 18. Selected pesticides detected and frequency of detections in groundwater and surface-water samples, by site, Cedar Rapids, lowa, calendar years 2006-10.

[LRL, laboratory reporting level; $\mu \mathrm{g} / \mathrm{L}$,micrograms per liter; E, estimate; ND, no detection]

\begin{tabular}{|c|c|c|c|c|c|c|c|}
\hline \multirow{2}{*}{ Pesticide } & \multirow{2}{*}{$\begin{array}{c}\text { Number of } \\
\text { detections/ } \\
\text { samples }\end{array}$} & \multirow{2}{*}{$\begin{array}{c}\mathrm{LRL}^{1} \\
(\mu \mathrm{g} / \mathrm{L})\end{array}$} & \multirow{2}{*}{$\begin{array}{c}\text { Number of } \\
\text { detectable } \\
\text { concentrations at } \\
\text { or greater than LRL }\end{array}$} & \multirow{2}{*}{$\begin{array}{c}\text { Number of } \\
\text { detectable con- } \\
\text { centrations less } \\
\text { than } \text { LRL }^{2}\end{array}$} & \multirow{2}{*}{$\begin{array}{l}\text { Percentage of } \\
\text { samples with } \\
\text { detectable } \\
\text { concentrations }\end{array}$} & \multicolumn{2}{|c|}{$\begin{array}{c}\text { Detectable } \\
\text { concentrations } \\
(\mu \mathrm{g} / \mathrm{L})\end{array}$} \\
\hline & & & & & & Maximum & Median \\
\hline \multicolumn{8}{|c|}{ 1993USGS CRM-3 } \\
\hline Atrazine & $8 / 8$ & 0.05 & 8 & 0 & 100 & 0.86 & 0.16 \\
\hline CIAT $^{3}$ & $8 / 8$ & .05 & 8 & 0 & 100 & .18 & .09 \\
\hline Metolachlor & $8 / 8$ & .05 & 4 & 4 & 100 & .28 & E.05 \\
\hline $\mathrm{CEAT}^{3}$ & $3 / 8$ & .05 & 2 & 1 & 37.5 & .09 & .08 \\
\hline Acetochlor & $2 / 8$ & .05 & 1 & 1 & 25 & .05 & E.035 \\
\hline Propazine & $2 / 8$ & .05 & 0 & 2 & 25 & E.02 & E.015 \\
\hline Simazine & $1 / 8$ & .05 & 0 & 1 & 12.5 & E.01 & E.01 \\
\hline Alachlor & $0 / 8$ & .05 & 0 & 0 & 0 & ND & ND \\
\hline Metribuzin & $0 / 8$ & .05 & 0 & 0 & 0 & ND & ND \\
\hline Carboxin & $0 / 8$ & .05 & 0 & 0 & 0 & ND & ND \\
\hline \multicolumn{8}{|c|}{ 1993USGS CRM-4 } \\
\hline Atrazine & $2 / 2$ & 0.05 & 0 & 2 & 100 & E.04 & E.04 \\
\hline CIAT $^{3}$ & $2 / 2$ & .05 & 2 & 0 & 100 & .08 & .15 \\
\hline Metolachlor & $2 / 2$ & .05 & 0 & 2 & 100 & E.02 & E.02 \\
\hline Carboxin & $1 / 2$ & .05 & 0 & 1 & 50 & E.02 & E.02 \\
\hline Acetochlor & $1 / 2$ & .05 & 0 & 1 & 50 & E.01 & E.01 \\
\hline $\mathrm{CEAT}^{3}$ & $0 / 2$ & .05 & 0 & 0 & 0 & ND & ND \\
\hline Propazine & $0 / 2$ & .05 & 0 & 0 & 0 & ND & ND \\
\hline Alachlor & $0 / 2$ & .05 & 0 & 0 & 0 & ND & ND \\
\hline Simazine & $0 / 2$ & .05 & 0 & 0 & 0 & ND & ND \\
\hline Metribuzin & $0 / 2$ & .05 & 0 & 0 & 0 & ND & ND \\
\hline \multicolumn{8}{|c|}{ 2009USGS CRM-4A } \\
\hline Atrazine & $4 / 4$ & 0.05 & 3 & 1 & 100 & 0.52 & 0.14 \\
\hline CIAT $^{3}$ & $4 / 4$ & .05 & 4 & 0 & 100 & .21 & .13 \\
\hline Metolachlor & $4 / 4$ & .05 & 3 & 1 & 100 & .19 & .07 \\
\hline $\mathrm{CEAT}^{3}$ & $2 / 4$ & .05 & 2 & 0 & 50 & .06 & .06 \\
\hline Acetochlor & $1 / 4$ & .05 & 0 & 1 & 25 & E.02 & E.02 \\
\hline Propazine & $1 / 4$ & .05 & 0 & 1 & 25 & E.01 & E.01 \\
\hline Alachlor & $0 / 4$ & .05 & 0 & 0 & 0 & ND & ND \\
\hline Simazine & $0 / 4$ & .05 & 0 & 0 & 0 & ND & ND \\
\hline Metribuzin & $0 / 4$ & .05 & 0 & 0 & 0 & ND & ND \\
\hline Carboxin & $0 / 4$ & .05 & 0 & 0 & 0 & ND & ND \\
\hline \multicolumn{8}{|c|}{ 1998USGS CRM-22 } \\
\hline Atrazine & $17 / 18$ & 0.05 & 16 & 1 & 94.4 & 1.11 & 0.085 \\
\hline CIAT $^{3}$ & $17 / 18$ & .05 & 17 & 0 & 94.4 & .24 & .085 \\
\hline Metolachlor & $17 / 18$ & .05 & 12 & 5 & 94.4 & .45 & .12 \\
\hline CEAT $^{3}$ & $4 / 18$ & .05 & 1 & 3 & 22.2 & .08 & E.02 \\
\hline
\end{tabular}


Table 18. Selected pesticides detected and frequency of detections in groundwater and surface-water samples, by site, Cedar Rapids, lowa, calendar years 2006-10.-Continued

[LRL, laboratory reporting level; $\mu \mathrm{g} / \mathrm{L}$,micrograms per liter; E, estimate; ND, no detection]

\begin{tabular}{|c|c|c|c|c|c|c|c|}
\hline \multirow{2}{*}{ Pesticide } & \multirow{2}{*}{$\begin{array}{c}\text { Number of } \\
\text { detections/ } \\
\text { samples }\end{array}$} & \multirow{2}{*}{$\begin{array}{c}\mathrm{LRL}^{1} \\
(\mu \mathrm{g} / \mathrm{L})\end{array}$} & \multirow{2}{*}{$\begin{array}{c}\text { Number of } \\
\text { detectable } \\
\text { concentrations at } \\
\text { or greater than LRL }\end{array}$} & \multirow{2}{*}{$\begin{array}{c}\text { Number of } \\
\text { detectable con- } \\
\text { centrations less } \\
\text { than } \mathrm{LRL}^{2}\end{array}$} & \multirow{2}{*}{$\begin{array}{l}\text { Percentage of } \\
\text { samples with } \\
\text { detectable } \\
\text { concentrations }^{2}\end{array}$} & \multicolumn{2}{|c|}{$\begin{array}{c}\text { Detectable } \\
\text { concentrations } \\
(\mu \mathrm{g} / \mathrm{L})\end{array}$} \\
\hline & & & & & & Maximum & Median \\
\hline \multicolumn{8}{|c|}{ 1998USGS CRM-22-Continued } \\
\hline Acetochlor & $3 / 18$ & .05 & 2 & 1 & 16.7 & .15 & .1 \\
\hline Propazine & $1 / 18$ & .05 & 0 & 1 & 5.6 & E.02 & E.02 \\
\hline Alachlor & $1 / 18$ & .05 & 0 & 1 & 5.6 & E.01 & E.01 \\
\hline Simazine & $1 / 18$ & .05 & 0 & 1 & 5.6 & E.02 & E.02 \\
\hline Metribuzin & $0 / 18$ & .05 & 0 & 0 & 0 & ND & ND \\
\hline Carboxin & $0 / 18$ & .05 & 0 & 0 & 0 & ND & ND \\
\hline \multicolumn{8}{|c|}{ 1998USGS CRM-23 } \\
\hline Atrazine & $4 / 4$ & 0.05 & 4 & 0 & 100 & 0.09 & 0.08 \\
\hline CIAT $^{3}$ & $4 / 4$ & .05 & 4 & 0 & 100 & .11 & E.06 \\
\hline Metolachlor & $4 / 4$ & .05 & 1 & 3 & 100 & .05 & E. 035 \\
\hline $\mathrm{CEAT}^{3}$ & $0 / 4$ & .05 & 0 & 0 & 0 & ND & ND \\
\hline Acetochlor & $0 / 4$ & .05 & 0 & 0 & 0 & ND & ND \\
\hline Propazine & $0 / 4$ & .05 & 0 & 0 & 0 & ND & ND \\
\hline Alachlor & $0 / 4$ & .05 & 0 & 0 & 0 & ND & ND \\
\hline Simazine & $0 / 4$ & .05 & 0 & 0 & 0 & ND & ND \\
\hline Metribuzin & $0 / 4$ & .05 & 0 & 0 & 0 & ND & ND \\
\hline Carboxin & $0 / 4$ & .05 & 0 & 0 & 0 & ND & ND \\
\hline \multicolumn{8}{|c|}{ 1990Seminole 17} \\
\hline Atrazine & $16 / 16$ & 0.05 & 16 & 0 & 100 & 0.44 & 0.13 \\
\hline CIAT $^{3}$ & $16 / 16$ & .05 & 16 & 0 & 100 & .16 & .08 \\
\hline Metolachlor & $16 / 16$ & .05 & 14 & 2 & 100 & .12 & .07 \\
\hline Acetochlor & $7 / 16$ & .05 & 2 & 5 & 43.8 & .1 & E.03 \\
\hline $\mathrm{CEAT}^{3}$ & $3 / 16$ & .05 & 1 & 2 & 18.8 & .05 & E.04 \\
\hline Propazine & $2 / 16$ & .05 & 0 & 2 & 12.5 & E.01 & E.01 \\
\hline Alachlor & $0 / 16$ & .05 & 0 & 0 & 0 & ND & ND \\
\hline Simazine & $0 / 16$ & .05 & 0 & 0 & 0 & ND & ND \\
\hline Metribuzin & $0 / 16$ & .05 & 0 & 0 & 0 & ND & ND \\
\hline Carboxin & $0 / 16$ & .05 & 0 & 0 & 0 & ND & ND \\
\hline \multicolumn{8}{|c|}{ Seminole 18} \\
\hline Atrazine & $12 / 12$ & 0.05 & 12 & 0 & 100 & 0.51 & 0.18 \\
\hline CIAT $^{3}$ & $12 / 12$ & .05 & 12 & 0 & 100 & .17 & .12 \\
\hline Metolachlor & $12 / 12$ & .05 & 9 & 3 & 100 & .12 & .06 \\
\hline Acetochlor & $6 / 12$ & .05 & 2 & 4 & 50 & .1 & Е.035 \\
\hline Propazine & $3 / 12$ & .05 & 0 & 3 & 25 & E.01 & E.007 \\
\hline CEAT $^{3}$ & $2 / 12$ & .05 & 0 & 2 & 16.7 & E.04 & E.04 \\
\hline Alachlor & $0 / 12$ & .05 & 0 & 0 & 0 & ND & ND \\
\hline Simazine & $0 / 12$ & .05 & 0 & 0 & 0 & ND & ND \\
\hline
\end{tabular}


Table 18. Selected pesticides detected and frequency of detections in groundwater and surface-water samples, by site, Cedar Rapids, lowa, calendar years 2006-10. - Continued

[LRL, laboratory reporting level; $\mu \mathrm{g} / \mathrm{L}$,micrograms per liter; E, estimate; ND, no detection]

\begin{tabular}{|c|c|c|c|c|c|c|c|}
\hline \multirow{2}{*}{ Pesticide } & \multirow{2}{*}{$\begin{array}{l}\text { Number of } \\
\text { detections/ } \\
\text { samples }\end{array}$} & \multirow{2}{*}{$\begin{array}{c}\text { LRL'1 }^{1} \\
(\mu \mathrm{g} / \mathrm{L})\end{array}$} & \multirow{2}{*}{$\begin{array}{c}\text { Number of } \\
\text { detectable } \\
\text { concentrations at } \\
\text { or greater than LRL }\end{array}$} & \multirow{2}{*}{$\begin{array}{c}\text { Number of } \\
\text { detectable con- } \\
\text { centrations less } \\
\text { than } \text { LRL }^{2}\end{array}$} & \multirow{2}{*}{$\begin{array}{l}\text { Percentage of } \\
\text { samples with } \\
\text { detectable } \\
\text { concentrations }{ }^{2}\end{array}$} & \multicolumn{2}{|c|}{$\begin{array}{c}\text { Detectable } \\
\text { concentrations } \\
(\mu \mathrm{g} / \mathrm{L})\end{array}$} \\
\hline & & & & & & Maximum & Median \\
\hline \multicolumn{8}{|c|}{ Seminole 18-Continued } \\
\hline Metribuzin & $0 / 12$ & .05 & 0 & 0 & 0 & ND & ND \\
\hline Carboxin & $0 / 12$ & .05 & 0 & 0 & 0 & ND & ND \\
\hline \multicolumn{8}{|c|}{ Ranney 1} \\
\hline Atrazine & $19 / 19$ & 0.05 & 18 & 1 & 100 & 0.68 & 0.08 \\
\hline CIAT $^{3}$ & $19 / 19$ & .05 & 19 & 0 & 100 & .17 & .09 \\
\hline Metolachlor & $19 / 19$ & .05 & 11 & 8 & 100 & .14 & .05 \\
\hline Acetochlor & $7 / 19$ & .05 & 2 & 5 & 36.8 & .09 & E.03 \\
\hline $\mathrm{CEAT}^{3}$ & $4 / 19$ & .05 & 2 & 2 & 21 & .05 & E.045 \\
\hline Propazine & $2 / 19$ & .05 & 0 & 2 & 10.5 & E.01 & E.01 \\
\hline Alachlor & $0 / 19$ & .05 & 0 & 0 & 0 & ND & ND \\
\hline Simazine & $0 / 19$ & .05 & 0 & 0 & 0 & ND & ND \\
\hline Metribuzin & $0 / 19$ & .05 & 0 & 0 & 0 & ND & ND \\
\hline Carboxin & $0 / 19$ & .05 & 0 & 0 & 0 & ND & ND \\
\hline \multicolumn{8}{|c|}{ Ranney 2} \\
\hline Atrazine & $19 / 19$ & 0.05 & 17 & 2 & 100 & 0.48 & 0.12 \\
\hline CIAT $^{3}$ & $19 / 19$ & .05 & 17 & 0 & 100 & .18 & .09 \\
\hline Metolachlor & $19 / 19$ & .05 & 13 & 6 & 100 & .16 & .07 \\
\hline Acetochlor & $8 / 19$ & .05 & 2 & 6 & 42.1 & .13 & E.03 \\
\hline CEAT $^{3}$ & $4 / 19$ & .05 & 1 & 3 & 21 & E.05 & E.04 \\
\hline Propazine & $1 / 19$ & .05 & 0 & 1 & 5.3 & E.01 & E.01 \\
\hline Alachlor & $0 / 19$ & .05 & 0 & 0 & 0 & ND & E.02 \\
\hline Simazine & $0 / 19$ & .05 & 0 & 0 & 0 & ND & ND \\
\hline Metribuzin & $0 / 19$ & .05 & 0 & 0 & 0 & ND & ND \\
\hline Carboxin & $0 / 19$ & .05 & 0 & 0 & 0 & ND & ND \\
\hline \multicolumn{8}{|c|}{ West Ranney 3} \\
\hline Atrazine & $18 / 18$ & 0.05 & 17 & 1 & 100 & 0.69 & 0.125 \\
\hline CIAT $^{3}$ & $18 / 18$ & .05 & 18 & 0 & 100 & .18 & .1 \\
\hline Metolachlor & $18 / 18$ & .05 & 11 & 7 & 100 & .3 & .055 \\
\hline Acetochlor & $7 / 18$ & .05 & 4 & 3 & 38.9 & .21 & E.05 \\
\hline CEAT $^{3}$ & $4 / 18$ & .05 & 1 & 3 & 22.2 & E.05 & E. 035 \\
\hline Propazine & $2 / 18$ & .05 & 0 & 2 & 11.1 & E.02 & E. 015 \\
\hline Alachlor & $1 / 18$ & .05 & 0 & 1 & 5.6 & E.03 & E.03 \\
\hline Metribuzin & $1 / 18$ & .05 & 0 & 1 & 5.6 & E.03 & E.03 \\
\hline Simazine & $0 / 18$ & .05 & 0 & 0 & 0 & ND & ND \\
\hline Carboxin & $0 / 18$ & .05 & 0 & 0 & 0 & ND & ND \\
\hline
\end{tabular}


Table 18. Selected pesticides detected and frequency of detections in groundwater and surface-water samples, by site, Cedar Rapids, lowa, calendar years 2006-10.-Continued

[LRL, laboratory reporting level; $\mu \mathrm{g} / \mathrm{L}$, micrograms per liter; E, estimate; ND, no detection]

\begin{tabular}{|c|c|c|c|c|c|c|c|}
\hline \multirow{2}{*}{ Pesticide } & \multirow{2}{*}{$\begin{array}{l}\text { Number of } \\
\text { detections/ } \\
\text { samples }\end{array}$} & \multirow{2}{*}{$\begin{array}{c}\mathrm{LRL}^{1} \\
(\mu \mathrm{g} / \mathrm{L})\end{array}$} & \multirow{2}{*}{$\begin{array}{c}\text { Number of } \\
\text { detectable } \\
\text { concentrations at } \\
\text { or greater than LRL }\end{array}$} & \multirow{2}{*}{$\begin{array}{c}\text { Number of } \\
\text { detectable con- } \\
\text { centrations less } \\
\text { than } \text { LRL }^{2}\end{array}$} & \multirow{2}{*}{$\begin{array}{l}\text { Percentage of } \\
\text { samples with } \\
\text { detectable } \\
\text { concentrations }{ }^{2}\end{array}$} & \multicolumn{2}{|c|}{$\begin{array}{c}\text { Detectable } \\
\text { concentrations } \\
(\mu \mathrm{g} / \mathrm{L})\end{array}$} \\
\hline & & & & & & Maximum & Median \\
\hline \multicolumn{8}{|c|}{ Seminole Ranney 4} \\
\hline Atrazine & $17 / 17$ & 0.05 & 16 & 1 & 100 & 0.56 & 0.14 \\
\hline CIAT $^{3}$ & $17 / 17$ & .05 & 17 & 0 & 100 & .21 & .09 \\
\hline Metolachlor & $17 / 17$ & .05 & 17 & 1 & 100 & .21 & .06 \\
\hline Acetochlor & $8 / 17$ & .05 & 3 & 5 & 47 & .14 & E. 035 \\
\hline $\mathrm{CEAT}^{3}$ & $5 / 17$ & .05 & 2 & 3 & 29.4 & .06 & E.04 \\
\hline Propazine & $0 / 17$ & .05 & 0 & 0 & 0 & ND & ND \\
\hline Alachlor & $0 / 17$ & .05 & 0 & 0 & 0 & ND & ND \\
\hline Simazine & $0 / 17$ & .05 & 0 & 0 & 0 & ND & ND \\
\hline Metribuzin & $0 / 17$ & .05 & 0 & 0 & 0 & ND & ND \\
\hline Carboxin & $0 / 17$ & .05 & 0 & 0 & 0 & ND & ND \\
\hline \multicolumn{8}{|c|}{ Cedar Rapids Waterworks } \\
\hline Atrazine & $19 / 19$ & 0.05 & 19 & 0 & 100 & 0.37 & 0.11 \\
\hline CIAT $^{3}$ & $19 / 19$ & .05 & 19 & 0 & 100 & .13 & .08 \\
\hline Metolachlor & $19 / 19$ & .05 & 11 & 8 & 100 & .16 & .06 \\
\hline Acetochlor & $8 / 19$ & .05 & 3 & 5 & 42.1 & .10 & E.035 \\
\hline CEAT $^{3}$ & $5 / 19$ & .05 & 0 & 5 & 26.3 & E.03 & E.03 \\
\hline Propazine & $2 / 19$ & .05 & 0 & 2 & 10.5 & E.01 & E.01 \\
\hline Alachlor & $1 / 19$ & .05 & 0 & 1 & 5.3 & E.01 & E.01 \\
\hline Metribuzin & $1 / 19$ & .05 & 0 & 1 & 5.3 & E.01 & E.01 \\
\hline Simazine & $0 / 19$ & .05 & 0 & 0 & 0 & ND & ND \\
\hline Carboxin & $0 / 19$ & .05 & 0 & 0 & 0 & ND & ND \\
\hline \multicolumn{8}{|c|}{ Cedar River at Edgewood Road } \\
\hline Atrazine & $17 / 17$ & 0.5 & 16 & 1 & 100 & 2.17 & 0.1 \\
\hline CIAT $^{3}$ & $17 / 17$ & .05 & 17 & 0 & 100 & .39 & .09 \\
\hline Metolachlor & $17 / 17$ & .05 & 14 & 3 & 100 & .84 & .06 \\
\hline Acetochlor & $9 / 17$ & .05 & 8 & 1 & 52.9 & .88 & .08 \\
\hline $\mathrm{CEAT}^{3}$ & $4 / 17$ & .05 & 3 & 1 & 23.5 & .15 & E.055 \\
\hline Propazine & $3 / 17$ & .05 & 0 & 3 & 17.6 & E.01 & E.01 \\
\hline Alachlor & $1 / 17$ & .05 & 0 & 1 & 5.9 & E.04 & E.04 \\
\hline Simazine & $1 / 17$ & .05 & 0 & 1 & 5.9 & E.02 & E.02 \\
\hline Metribuzin & $0 / 17$ & .05 & 0 & 0 & 0 & ND & ND \\
\hline Carboxin & $0 / 17$ & .05 & 0 & 0 & 0 & ND & ND \\
\hline
\end{tabular}

${ }^{1}$ Highest laboratory reporting limit for period of record.

${ }^{2}$ Includes both quantifiable and unquantifiable (estimated) concentrations. Quantifiable detections are concentrations that exceeded lower laboratory reporting limits during period of record.

${ }^{3}$ Atrazine degradates: 2-Chloro-4-amino-6-isopropyl-amino-striazine (CIAT) and 2-Chloro-4-ethylamino-6-amino-s-triazine (CEAT). 
Table 19. Virus in groundwater and surface-water samples, by site, Cedar Rapids, lowa, calendar years 2006-10.

[LIMS ID, Laboratory Information Management System Identification number; gc/Tv, genomic copies per total volume sampled; ND, not detected; NA, not available; DNQ, detected, not quantified; E, estimated; NA, not available]

\begin{tabular}{|c|c|c|c|c|c|c|}
\hline $\begin{array}{c}\text { Date } \\
\text { (year, month, day) }\end{array}$ & $\begin{array}{c}\text { Time } \\
\text { (24-hour) }\end{array}$ & LIMS ID & $\begin{array}{c}\text { Adenovirus } \\
\text { (gc/Tv) }\end{array}$ & $\begin{array}{c}\text { Enterovirus } \\
\text { (gc/Tv) }\end{array}$ & $\begin{array}{c}\text { Norovirus } \mathrm{GI}^{1} \\
\text { (gc/Tv) }\end{array}$ & $\begin{array}{c}\text { Norovirus GII' } \\
\text { (gc/Tv) }\end{array}$ \\
\hline \multicolumn{7}{|c|}{ 1998USGS CRM-3 } \\
\hline 20080519 & 1250 & $1122-01$ & ND & ND & ND & ND \\
\hline 20080804 & 1600 & $1226-01$ & ND & NA & ND & ND \\
\hline 20081009 & 1110 & $1305-01$ & ND & ND & ND & ND \\
\hline 20090608 & 1035 & 1493-01 & ND & ND & ND & ND \\
\hline 20090915 & 0955 & $1642-01$ & ND & ND & ND & ND \\
\hline \multicolumn{7}{|c|}{ 2010USGS CRM-4A } \\
\hline 20100720 & 1020 & $1758-01$ & ND & ND & ND & ND \\
\hline 20100909 & 0905 & 1794-01 & ND & ND & ND & ND \\
\hline \multicolumn{7}{|c|}{ 1998USGS CRM-22 } \\
\hline 20080514 & 1345 & 1119-01 & ND & ND & ND & ND \\
\hline 20080731 & 1035 & $1222-01$ & ND & NA & ND & DNQ \\
\hline 20081014 & 1145 & $1306-01$ & ND & ND & ND & ND \\
\hline 20090402 & 1115 & $1390-01$ & ND & ND & ND & ND \\
\hline 20090609 & 1150 & $1495-01$ & ND & ND & ND & ND \\
\hline \multicolumn{7}{|c|}{ Seminole 17} \\
\hline 20080513 & 1230 & $1116-01$ & ND & ND & ND & ND \\
\hline 20080729 & 0940 & 1219-01 & DNQ & NA & ND & DNQ \\
\hline 20081006 & 0945 & 1296-01 & ND & ND & ND & ND \\
\hline 20090402 & 1115 & $1390-01$ & ND & ND & ND & ND \\
\hline 20090602 & 1055 & $1483-02$ & ND & ND & ND & ND \\
\hline 20090910 & 1030 & $1637-01$ & DNQ & ND & ND & ND \\
\hline 20100721 & 1120 & $1762-01$ & ND & ND & ND & ND \\
\hline \multicolumn{7}{|c|}{ Seminole Ranney 4} \\
\hline 20080515 & 1145 & 1121-01 & ND & ND & ND & ND \\
\hline 20080730 & 0956 & $1221-01$ & ND & ND & ND & ND \\
\hline 20081007 & 1135 & 1299-01 & ND & ND & ND & ND \\
\hline 20090604 & 1005 & $1490-01$ & ND & ND & ND & ND \\
\hline 20090908 & 1040 & $1635-01$ & 61 & ND & ND & ND \\
\hline 20090908 & 1045 & $1635-02$ & ND & ND & ND & ND \\
\hline 20100719 & 1015 & $1757-01$ & ND & ND & ND & ND \\
\hline 20100719 & 1020 & $1757-02$ & ND & ND & ND & ND \\
\hline 20100830 & 1520 & 1783-02 & ND & ND & ND & ND \\
\hline \multicolumn{7}{|c|}{ Cedar Rapids Waterworks (raw water) } \\
\hline 20090407 & 1045 & $1396-01$ & ND & ND & ND & ND \\
\hline 20090930 & 1140 & $1648-01$ & ND & ND & ND & ND \\
\hline 20090602 & 1025 & 1483-01 & $36 \mathrm{E}$ & ND & ND & ND \\
\hline 20100316 & 0900 & $1697-01$ & ND & ND & ND & ND \\
\hline 20100615 & 0830 & $1735-01$ & ND & ND & ND & ND \\
\hline 20100831 & 1510 & $1786-01$ & ND & ND & ND & ND \\
\hline
\end{tabular}


Table 19. Virus in groundwater and surface-water samples, by site, Cedar Rapids, lowa, calendar years 2006-10.-Continued

[LIMS ID, Laboratory Information Management System Identification number; gc/Tv, genomic copies per total volume sampled; ND, not detected; NA, not available; DNQ, detected, not quantified; E, estimated; NA, not available]

\begin{tabular}{ccccccc}
\hline $\begin{array}{c}\text { Date } \\
\text { (year, month, day) }\end{array}$ & $\begin{array}{c}\text { Time } \\
\text { (24-hour) }\end{array}$ & LIMS ID & $\begin{array}{c}\text { Adenovirus } \\
\text { (gc/Tv) }\end{array}$ & $\begin{array}{c}\text { Enterovirus } \\
\text { (gc/Tv) }\end{array}$ & $\begin{array}{c}\text { Norovirus GI } \\
\text { (gc/Tv) }\end{array}$ & $\begin{array}{c}\text { Norovirus GII' } \\
\text { (gc/Tv) }\end{array}$ \\
\hline 20100315 & 1210 & $1696-01$ & ND & ND & ND & ND \\
20100615 & 1520 & $1735-02$ & ND & ND & ND & ND \\
20100830 & 1625 & $1783-01$ & ND & ND & ND & ND \\
\hline 20080520 & 1615 & $1126-01$ & DNQ & ND & ND & $3,400 E$ \\
20080805 & 0945 & $1228-01$ & DNQ & ND & ND & ND \\
20090402 & 1020 & $1390-02$ & 130 & ND & ND & ND \\
20090603 & 1014 & $1487-01$ & $21 E$ & ND & ND & DNQ \\
20090909 & 0920 & $1636-01$ & ND & ND & ND & ND \\
20100323 & 1536 & $1705-01$ & ND & ND & ND & ND \\
20100614 & 1800 & $1733-01$ & ND & ND & ND & ND \\
20100908 & 1535 & $1792-01$ & ND & ND & ND & ND \\
\hline
\end{tabular}

${ }^{1}$ Norovirus cannot be accurately quantified since it cannot grow in cultured cells like other enteric viruses. Norovirus positive controls are obtained from positive stool samples from the local health department. Estimated quantities are given because the true limit of quantification cannot be known until an accurate method is developed. Therefore, low levels of norovirus may be present in these samples (Erin Stelzer, U.S. Geological Survey, Ohio Water Microbiology Laboratory, written commun., 2011). 

Publishing support provided by:

Rolla Publishing Service Center

For more information concerning this publication, contact:

Director, USGS lowa Water Science Center

P.O. Box 1230

lowa City, IA 52244

(319) 337-4191

Or visit the lowa Water Science Center Web site at: http://ia.water.usgs.gov/ 

